
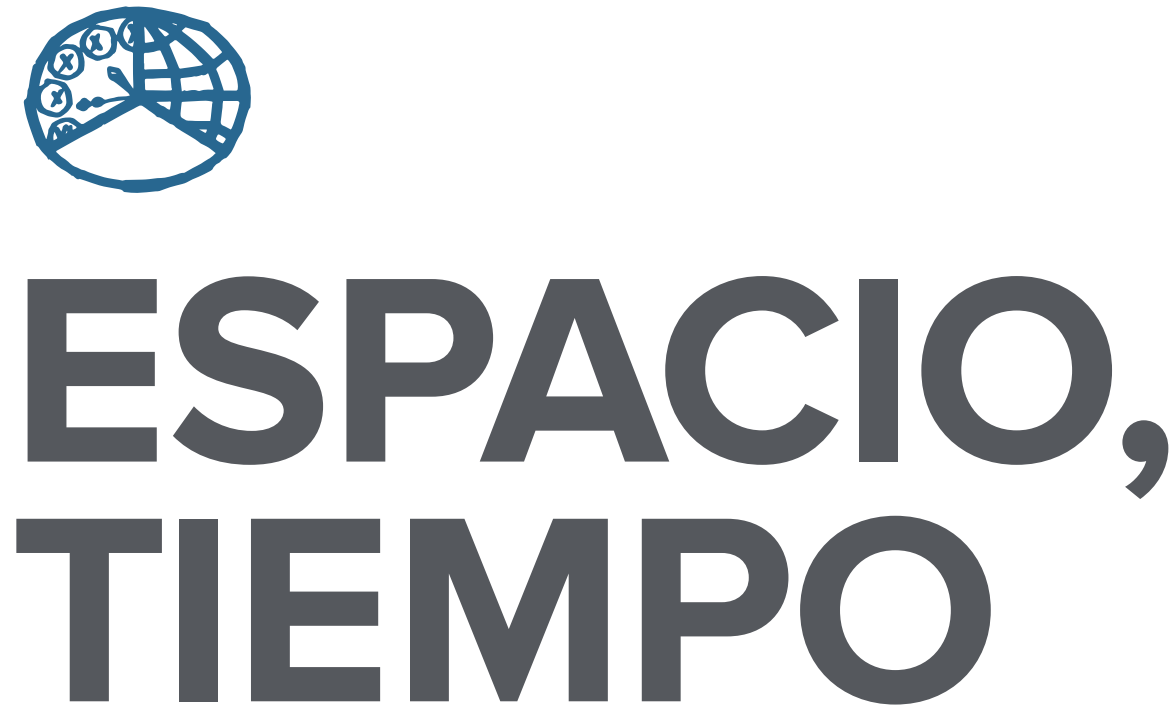

AÑO 2013

NUEVA ÉPOCA

ISSN 1130-4715

E-ISSN 2340-1478
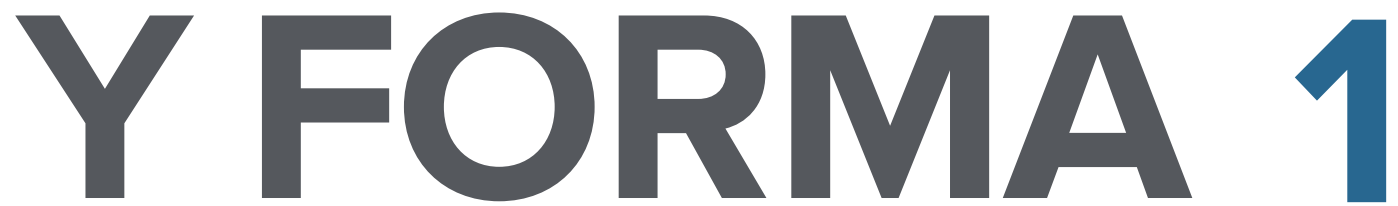

SERIE VII HISTORIA DEL ARTE

REVISTA DE LA FACULTAD DE GEOGRAFÍA E HISTORIA 

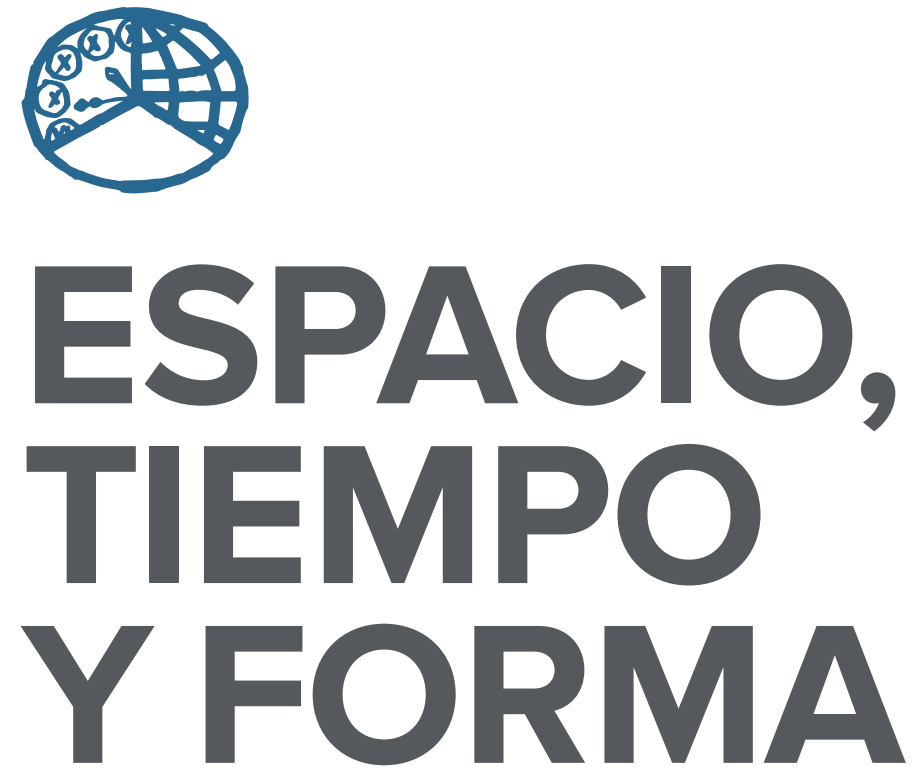

AÑO 2013

NUEVA ÉPOCA

ISSN $1130-4715$

E-ISSN 2340-1478

SERIE VII HISTORIA DEL ARTE

REVISTA DE LA FACULTAD DE GEOGRAFÍA E HISTORIA

http://dx.doi.org/10.5944/etfvii.1.2013

\section{UกED}

UNIVERSIDAD NACIONAL DE EDUCACIÓN A DISTANCIA 
La revista Espacio, Tiempo y Forma (siglas recomendadas: ETF), de la Facultad de Geografía e Historia de la UNED, que inició su publicación el año 1988, está organizada de la siguiente forma:

$$
\begin{aligned}
& \text { SERIE I - Prehistoria y Arqueología } \\
& \text { SERIE II - Historia Antigua } \\
& \text { SERIE III - Historia Medieval } \\
& \text { SERIE IV - Historia Moderna } \\
& \text { SERIE V - Historia Contemporánea } \\
& \text { SERIE VI - Geografía } \\
& \text { SERIE VII - Historia del Arte }
\end{aligned}
$$

Excepcionalmente, algunos volúmenes del año 1988 atienden a la siguiente numeración:

$$
\begin{aligned}
& \mathrm{N}^{\circ} 1 \text { - Historia Contemporánea } \\
& \mathrm{N}^{\circ} 2 \text { - Historia del Arte } \\
& \mathrm{N}^{\circ} 3 \text { - Geografía } \\
& \mathrm{N} .^{\circ} 4 \text { - Historia Moderna }
\end{aligned}
$$

ETF no se solidariza necesariamente con las opiniones expresadas por los autores.

Espacio, Tiempo y Forma, Serie vII está registrada e indexada, entre otros, por los siguientes Repertorios Bibliográficos y Bases de Datos: DICE, ISOC (CINDOC), RESH, IN-RECH, Dialnet, e-spacio, UNED, CIRC, MIAR, FRANCIS, PIO, Ulrich's, SUDOC, 2DB, ERIH (ESF).

\author{
UNIVERSIDAD NACIONAL DE EDUCACIÓN A DISTANCIA \\ Madrid, 2013 \\ SERIE VII · HISTORIA DEL ARTE (NUEVA ÉPOCA) N. ${ }^{\circ} 1,2013$ \\ ISSN $1130-4715 \cdot$ E-ISSN 2340-1478 \\ DEPÓSITO LEGAL \\ $M-21.037-1988$ \\ URL \\ ETF VII · HISTORIA DEL ARTE · http://revistas.uned.es/index.php/ETFVII \\ DISEÑO Y COMPOSICIÓN \\ Ángela Gómez Perea · http://angelagomezperea.com \\ Sandra Romano Martín · http://sandraromano.es \\ Impreso en España · Printed in Spain
}

(c) (1) (8) Esta obra está bajo una licencia Creative Commons

Reconocimiento-NoComercial 4.0 Internacional. 


\title{
EL ARQUITECTO MADRILEÑO \\ PEDRO DE LA TORRE EN TOLEDO \\ Y UN RETABLO INÉDITO LOCALIZADO
}

\author{
THE ARCHITECT OF MADRID \\ PEDRO DE LA TORRE IN TOLEDO \\ AND A LOCATED UNPUBLISHED ALTARPIECE
}

\author{
Antonio José Díaz Fernández ${ }^{1}$ \\ Recibido: 24/06/2013 - Aprobado: 19/11/2013 \\ http://dx.doi.org/10.5944/etfvii.1.2013.8287
}

\section{Resumen}

Entre las realizaciones del arquitecto barroco Pedro de la Torre para la ciudad de Toledo es posible identificar un retablo hasta ahora inédito, datado en i653 y en el que colabora el ensamblador toledano Juan García de San Pedro, localizado hoy en la parroquia de Nambroca (Toledo), en el que se aprecian las innovaciones estructurales y ornamentales propias del lenguaje desarrollado por el artista.

\section{Palabras clave}

arte toledano del s. xvıı; barroco madrileño; Juan García de San Pedro; Nambroca; Pedro de la Torre; retablo barroco; Toledo

\section{Abstract}

Among the works of the baroque architect Pedro de la Torre for the city of Toledo is possible to identify an up to now unpublished altarpiece in which collaborates the Toledan assembler Juan García de San Pedro. Dated in I653 and at present located in the parish of Nambroca (Toledo), in which we can appreciate the typical structural and ornamental innovations of the language developed by the artist.

\section{Keywords}

baroque altarpiece; Juan García de San Pedro; Madrilenian baroque; Nambroca; Pedro de la Torre; Toledan art of the $\mathrm{I}^{\text {th }}$ century; Toledo

1. Doctor en Historia del Arte, UNED (ajdiazf@terra.com). 


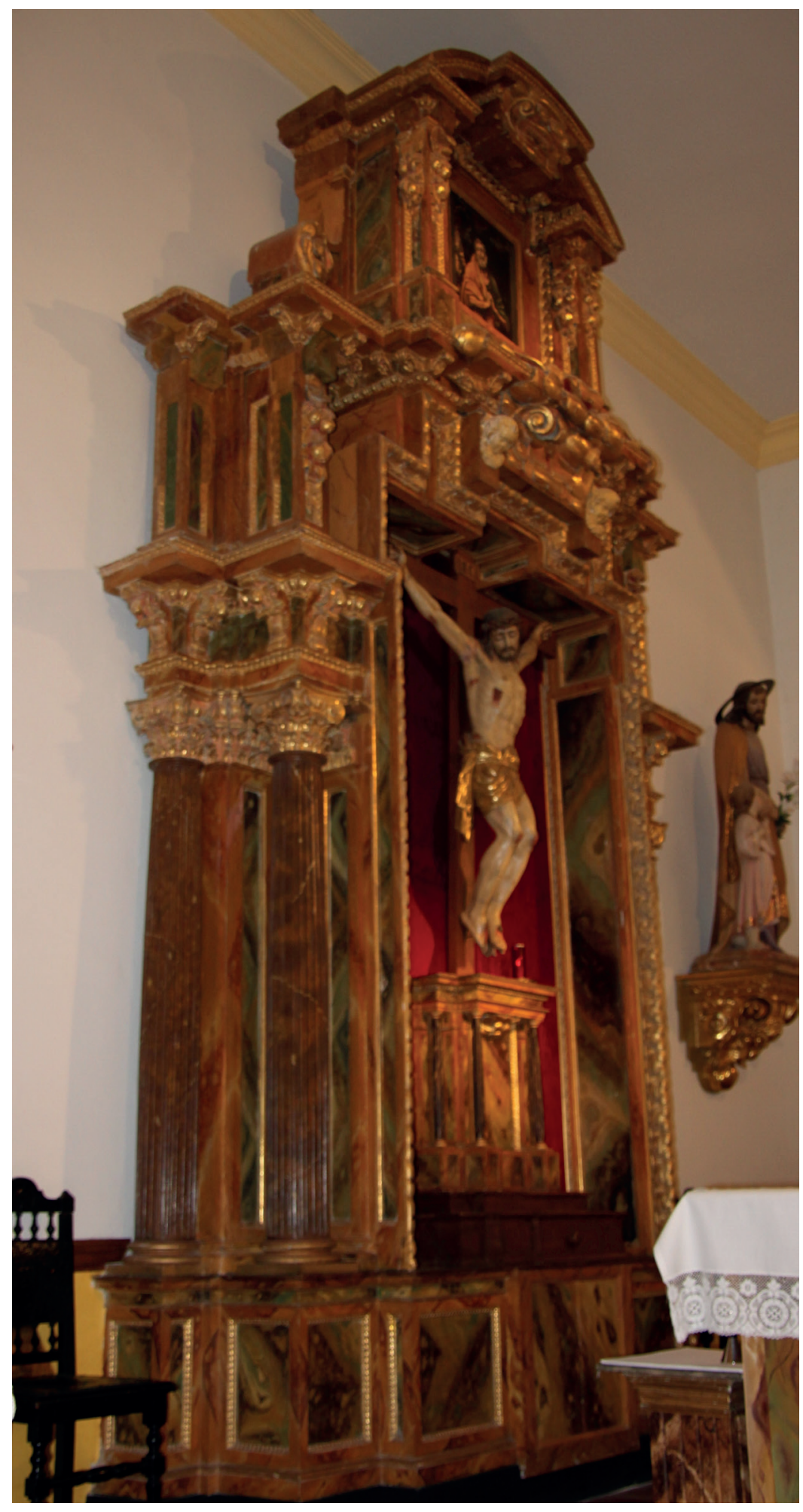

FIGURA 1. RETABLO «MAYOR》 (ANTIGUO RETABLO DEL SANTO CRISTO DE LA BUENA MUERTE)

Nambroca (Toledo). Iglesia parroquial de Ntra. Sra. de la Purificación.

Traza de Pedro de la Torre y obra de Juan García de San Pedro (1652). (Fotos del autor) 
LA CULTURA ARTÍSTICA DEL BARROCO en Toledo debe al arquitecto Pedro de la Torre (I596-1677) una serie de aportaciones indiscutibles a través, sobre todo, de sus intervenciones catedralicias tanto de índole arquitectónica como de alcance decorativo, que en su amplio sentido artístico inciden en la superación del post-clasicismo que inmovilizaba la arquitectura y artes toledanas de la primera mitad del siglo xviı. Esta influencia se desprende aún más a través de las manifestaciones artísticas de carácter retablístico realizadas por el célebre arquitecto y que se concretan en una obra inédita que nos proponemos documentar in extenso aunque ya fuera señalada su previsible importancia en un trabajo reciente ${ }^{2}$.

\section{PEDRO DE LA TORRE Y LOS ARTISTAS TOLEDANOS}

En nada ajeno al medio toledano, el madrileño Pedro de la Torre, si bien de origen conquense, entabló continuas relaciones profesionales con artistas de la Ciudad Imperial creando importantes vínculos que habrían de procurar la introducción en Toledo de nuevos formalismos artísticos. Algo ya visto en el caso temprano de la obra del retablo mayor de la iglesia de Pinto (Madrid) en la que por la autoridad eclesiástica de la sede primada se le asocia al escultor toledano Francisco González de Bargas en virtud de la sentencia dictada en el pleito por la adjudicación de la obra; la que debía de construir en un principio y por mandato arzobispal de i632 el escultor toledano Miguel González, su padre, pero cuya traza y ejecución conjunta recayó luego en i637 en el madrileño y en el joven González 3 .

También por esos mismos años Pedro de la Torre hubo de tratar al maestro de arquitectura toledano Alonso García Becerro, quien muestra decididos rasgos barrocos a la hora de trazar en I64I el retablo mayor del convento de carmelitas descalzas de San José de Toledo, claramente influenciado por lo madrileño para ser de idea y mano de artífice formado en taller local ${ }^{4}$. El mismo arquitecto que declaraba en su última voluntad, otorgada en Toledo en 5 de septiembre de I647, una deuda existente entre ambos y con ocasión de algún negocio no precisado, expresando estar debiendo «a Pedro de la Torre escultor vecino de la villa de Madrid setecientos Reales de vellon por escrip. ${ }^{\text {a }}$ de obligaçion y para en quenta de ellos le tengo pagados veinte y dos Reales de a ocho de plata, mando se le pague lo demas»5. Una cercanía de trato que se revelaba años atrás en la visita que juntos, y etiquetados de arquitectos

\footnotetext{
2. Díaz Fernández, Antonio José: «En torno a la caracterización barroca del retablo toledano del siglo XVII», Anales de Historia del Arte, 22 (2012), pp. 103-123.

3. Corella SuÁrez, Pilar: Arquitectura religiosa de los siglos xvII y xvIII en la provincia de Madrid. Estudio y documentación del partido judicial de Getafe. Madrid, 1979, pp. 100-102. Es así con la colaboración previa de Francisco González, quien habría asumido en solitario el proyecto desde 30 de junio de 1635, cuando el Consejo de Gobernación del arzobispado le encargó como tal escultor y arquitecto la obra de madera, escultura, talla y ensamblaje de la custodia y retablo del altar mayor «como lo estava a Miguel Gonzalez, su padre», vid. GUTIÉRREZ GARCíA-BRAZALES, Manuel: Artistas y artífices en el arzobispado de Toledo. Toledo, 1982, p. 335. Retablo en el que predomina la concepción artística de Pedro de la Torre sobre una labor poco precisada del toledano Francisco González.

4. Díaz Fernández, Antonio José: «Presencia del barroco madrileño en Toledo: el retablo mayor de las carmelitas descalzas y su autor Alonso García Becerro», Goya: Revista de arte, 34 (2012), pp. 300-311.

5. Idem, pp. 308-309.
} 
madrileños, giraban a Salamanca en 29 de octubre de I635 para tasar por parte del ensamblador Antonio González Ramiro y su socio el escultor Antonio de Paz la obra del retablo mayor de la parroquia de San Martín de esa ciudad castellana ${ }^{6}$.

Pero más frecuente se volvió el contacto con el maestro mayor de obras de Toledo Juan García de San Pedro, con quien Pedro de la Torre llegó a compartir un par de encargos retablísticos desde i652, uno inédito en la propia ciudad de Toledo, el que es objeto de este estudio, y otro más ambicioso en la villa condal de Orgaz (Toledo), ya publicado.

También sabemos de esporádicos encuentros con un joven maestro de escultor y arquitecto toledano de nombre Juan Gómez Lobo, dado que a finales de diciembre de 1656 el contrato de un retablo en la capilla de Ntra. Sra. del Buen Suceso de la iglesia parroquial de Santa María Magdalena de la ciudad de Toledo revela entre las cláusulas la imposición de la cofradía comitente de someter a juicio de Pedro de la Torre, maestro de arquitectura, la traza y condiciones dadas por Gómez Lobo, que lo debería tener asentado a mediados del año $1658^{7}$. Con nuevos contactos si no personales sí alrededor, sin duda, de los trabajos decorativos para el Ochavo catedralicio diseñados por Pedro de la Torre, algunas de cuyas piezas, entre tarjetas, colgantes y festones de talla, fueron realizadas en madera entre i662 y I663 por Gómez Lobo como modelos previos a su vaciado en bronce ${ }^{8}$.

\section{LOS PRECEDENTES ARTÍSTICOS DE PEDRO DE LA TORRE}

Un breve repaso a la actividad artística de Pedro de la Torre, centrada principalmente en la ciudad de Madrid, nos revela que hasta I64I, y después de su breve

6. Dato publicado por Rodríguez G. de Ceballos, Alfonso \& Casaseca Casaseca, Antonio: «Antonio y Andrés de Paz y la escultura de la primera mitad del siglo xvı en Salamanca», B.S.A.A., 45 (1979), pp. 395-397. No existe ninguna relación de pupilaje puesto que Alonso García Becerro está documentado en Toledo como discípulo de Juan García de San Pedro, del que será su yerno desde 1635, vid. DíAz FERnÁNDEZ, Antonio José: op. cit., pp. $305-306$.

7. Archivo Histórico Provincial de Toledo (AHPT), Protocolos, n. ${ }^{\circ}$ 3578, fol. 396, escribano José Moya Loaisa. Contratan Juan Mateos y Pedro Carrasco Marín, mayordomos de la cofradía, con Juan Gómez Lobo «maestro deescultor» vecino de Toledo, conforme a planta de su mano y con las siguientes condiciones: «q - se an de guardar las enmiendas que pedro de la torre Maestro de arquitecto tiene fechas y adbertidas al dicho Ju. ${ }^{\circ}$ gomez lobo y constan por un papel firmado del dicho pedro de la torre que queda en poder del presente ssn. ${ }^{\circ}$ juntamente con otras condiciones que por menor tiene fechas el dicho ju. ${ }^{\circ}$ gomez lobo en bista a la execucion de la planta que tanbien esta firmado de su nonbre sin que se entienda que estas condiciones ni las adbertencias fechas por el dho P..$^{\circ}$ de la torre se contradigan en cosa alguna porque de todo ello se a de guardar y executar lo $q$ - fuere mas conbeniente y mas realze para la ffabrica del dicho retablo y arquitestura [...] que estando acabado el dicho retablo y sentado en la dicha capilla lo a de ber el dicho P. ${ }^{\circ}$ de la torre u otro qualquier maestro o maestros que se nonbraren por las partes para que declaren si a cumplido con las condiciones y executado la dicha planta donde no lo a de enmendar a su costa en todo lo que ubiere faltado sigun la dicha planta esto en quanto a lo que constare por dichas declaraciones...». Desconocemos si una de estas sugerencias de Pedro de la Torre fue la de recomendar al escultor madrileño Manuel Correas para realizar la escultura del retablo, particularmente las imágenes de San Joaquín y Santa Ana que la bibliografía local reconoce suyas, vid. Ramirez de Arellano, Rafael: Las Parroquias de Toledo. Toledo, 1997 (ed. facs. Toledo 1921), p. 184.

8. Zarco del Valle, Manuel R.: Datos documentales para la Historia del Arte español. " Documentos de la Catedral de Toledo. 2 v., Madrid, 1916, t. II, pp. 339-340. Juan Gómez Lobo (†1679) es el arquitecto de retablos más reconocido de la segunda mitad del siglo XVII en Toledo, quien asienta la tipología afín a las propuestas de Pedro de la Torre y quien introduce el uso de la columna salomónica, vid. DíAz FERNÁNDEZ, Antonio José: «Origen y presencia de la columna salomónica en el retablo barroco toledano», Toletum, 49 (2004), pp. 143-190. 
paso por el País Vasco entre i639 y i640, tenía realizadas varias obras mencionadas principalmente por Tovar, Agulló y Cobo y otros autores ${ }^{9}$, como eran el retablo mayor de la iglesia conventual de las Maravillas (I624), el retablo de Ntra. Sra. de las Angustias y Soledad en San Felipe el Real (I630), el retablo mayor de la iglesia de Centenera en Guadalajara (I63I), el retablo mayor del hospital del Buen Suceso, con las primeras columnas de orden salomónico alzadas en la Corte (I635-37) y el aludido retablo mayor de Santo Domingo de Silos, de la parroquial de Pinto (I637); a los que se suman los encargos del retablo mayor de la parroquia guipuzcoana de Tolosa (I639-I647) y del retablo mayor del santuario bilbaíno de Ntra. Sra. de Begoña (I640). Todos desaparecidos menos el monumental retablo-hornacina de Pinto.

Otra etapa se abre con el retablo mayor de la iglesia parroquial de Santiago de Madrid (I642) ${ }^{\mathrm{IO}}$, seguido por dos obras bien conservadas como son el retablo de la capilla de San Marcos de la iglesia segoviana de Martín Muñoz de las Posadas, en colaboración con Juan Bautista Garrido (I643) ${ }^{\mathrm{II}}$, y el mayor del santuario de Ntra. Sra. de la Fuencisla en la ciudad de Segovia (I645), aquí en compañía del inseparable lego jesuita Francisco Bautista y perfeccionando el prototipo de retablo-camarín ${ }^{\mathrm{I} 2}$; mientras que no hay apenas más noticias suyas entre I646, fecha de su participación en el túmulo del Príncipe Baltasar Carlos levantado por el ayuntamiento en la iglesia de Santo Domingo el Real de Madrid ${ }^{13}$, y I65I, año en que se contrata el entierro de don Antonio de Camporredondo y Río en los carmelitas descalzos de Valladolid, según sus trazas ${ }^{14}$.

Si bien, Pedro de la Torre se hallaría ocupado con otros destacados artistas madrileños, entre los meses de abril y agosto de I649, en las decoraciones efímeras para la entrada en la Villa y Corte de la segunda esposa de Felipe iv, la reina Mariana de Austria ${ }^{15}$. Después de su polifacética intervención en la catedral de Toledo también a partir de I647, de la que haremos reseña, vuelven los retablos como los tres de cabecera de la iglesia de monjas mercedarias de don Juan de Alarcón (i654)

9. Tovar Martín, Virginia: «El arquitecto-ensamblador Pedro de la Torre», A.E.A., 183 (1973), pp. 261-298; AGULLó y COBO, Mercedes: «Pedro, José, Francisco y Jusepe de la Torre, arquitectos de retablos», A.I.E.M., 37 (1997), pp. 25-70; BARRIO MoYA, José L.: «El retablo mayor y otras obras perdidas de Pedro de la Torre en la iglesia de Centenera», Wad-al-Haiara, 7 (1980), pp. 319-323. Antes de establecerse en Madrid, de Pedro de la Torre se documenta en Guadalajara el contrato de una custodia y un retablo mayor para la iglesia de Ntra. Sra. de la Fuente entre 1620 y 1621, sin que estas obras llegaran a ejecutarse, vid. JıMÉnEz MuÑoz, José Miguel: «El retablo mayor de Ntra. Sra. de la Fuente de Guadalajara (1620-21): primera obra conocida del arquitecto-ensamblador Pedro de la Torre», en Actas del I Congreso de Historia de Castilla-La Mancha, Servicio de Publicaciones Junta de Comunidades de Castilla-La Mancha, Toledo, t. VII, 1988, pp. 427-433.

10. Cruz Yábar, Juan M. a: «Los retablos de la parroquia de Santiago de Madrid, Pedro de la Torre, Sebastián de Benavente y Alonso Cano», A.I.E.M., 45 (2005), pp. 155-178. Tovar Martín, Virginia: op. cit., p. 282.

11. Agulló y Сово, Mercedes: «Manuel Pereira: Aportación documental», B.S.A.A., 44 (1977), pp. 257-278. En agosto de 1644 Pedro de la Torre firma en Madrid como testigo al otorgamiento del testamento de su amigo y colega Juan Bautista Garrido, vid. AgulLó y Сово, Mercedes: Documentos sobre escultores, entalladores y ensambladores de los siglos XVI al XVIII. Valladolid, 1978, p. 74.

12. Tovar Martín, Virginia: op. cit., pp. 283-284. Martín GonzÁlez, Juan José: El retablo barroco en España. Madrid, 1993, p. 94.

13. Agulló y Совo, Mercedes: «Pedro, José, Francisco...», p. 32.

14. Idem, pp. 32-33. Esta obra hubiera podido descubrir la faceta escultórica de Pedro de la Torre, vid. BARRIO MoYA, José L.: «Sobre una obra desaparecida de Pedro de la Torre en Valladolid», B.S.A.A., 49 (1983), pp. 484-486.

15. Agulló y Сово, Mercedes: «Addenda a Pedro de la Torre», A.I.E.M., 38 (1998), pp. 177-194. 
a la vez que el ensanche del retablo mayor de los agustinos recoletos de Madrid ${ }^{16} \mathrm{y}$ la traza para el retablo mayor de Santa María de Tordesillas en Valladolid (I655) ${ }^{17}$. Todas ellas, obras que ayudan a contextualizar la actividad que habría de desarrollar Pedro de la Torre en Toledo en torno a $165 \mathrm{O}^{18}$.

\section{PEDRO DE LA TORRE EN TOLEDO}

En este entramado de realizaciones y cubriendo en parte esa laguna de datos antes advertida en torno a la mitad de la centuria, cabe explorar la presencia física de Pedro de la Torre en Toledo como gran maestro de arquitectura y su intervención puntual en varios diseños circunscritos al área toledana, que por orden cronológico son:

I. I647. El modelo de trono y arco de la Virgen del Sagrario para el altar de su capilla de la catedral primada, a realizar en plata.

2. I652. Un retablo secundario de la iglesia de la Trinidad Calzada de Toledo, que, repetimos, es el objeto de este trabajo.

3. I653. El retablo mayor de la parroquia de Santo Tomás Apóstol, en la villa de Orgaz.

Si bien, un último encargo al final de su carrera también le relaciona con Toledo, tratándose del desaparecido retablo mayor de la parroquia de San Andrés de Casarrubios del Monte, pues según refiere en su testamento otorgado en Madrid en 23 de noviembre de 1676 el arquitecto dice tener cuentas pendientes de la obra del retablo mayor y custodia de la citada parroquia, que había hecho con su sobrino Francisco de la Torre ${ }^{\mathrm{I}}$.

Aunque éstas son sólo las materializaciones del arte de Pedro de la Torre en Toledo, sin embargo, conviene seguir el curso de sus idas y venidas a la ciudad y

16. Agulló y Совo, Mercedes: «Pedro, José, Francisco...», pp. 34-35; Hernández Núñez, Juan Carlos: «La iglesia conventual de Don Juan de Alarcón de Madrid y el Patronato de los Cortizos», Reales Sitios, 167 (2006), p. 57.

17. Tovar Martín, Virginia: op. cit., pp. 292-293.

18. A partir de aquí se suceden en Madrid capital el retablo mayor de monjas benitas de la Encarnación de San Plácido (1658-64), en colaboración con su primo José de la Torre, vid. AGULLó y CoBo, Mercedes: «El monasterio de San Plácido y su fundador, el madrileño don Jerónimo de Villanueva Protonotario de Aragón», Villa de Madrid, XII, 47 (1975), pp. 37-50; el monumento funerario para el rey Pedro I en Santo Domingo el Real (1659), el retablo para Ntra. Sra. del Rosario y Santo Nombre de Jesús, de los dominicos de Santo Tomás (1662), el retablo de la capilla de Santo Cristo de la Salud del convento hospitalario de Antón Martín (1663), el mayor de la iglesia benedictina de Montserrat (1668), el del Santísimo Cristo de la Fe de la parroquia de San Sebastián (1670), vid. AgulLó y Cobo, Mercedes: «Pedro, José, Francisco...», pp. 36-40; y en la provincia el retablo mayor de la parroquia de San Pedro de Vallecas (1670), vid. DíAz FERnÁNDEZ, Antonio José: «El retablo mayor de la parroquial de Vallecas (Madrid): una arquitectura desaparecida de Pedro y Francisco de la Torre (1672)», Espacio, Tiempo y Forma, Serie VII, H. ${ }^{a}$ del Arte, 17 (2004), pp. 149-172.

19. Tovar Martín, Virginia: op. cit., p. 265. Ponz lo describió en su emplazamiento original así: «en el retablo principal de la parroquia de San Andrés, que, aunque no del mejor tiempo, tampoco es disparatado, hay un cuadro en medio, que representa al santo titular, obra, según el estilo, de las mejores de Francisco Ignacio Ruiz de la Iglesia, de quien son otras pinturas del zócalo; hay también en el retablo algunas obras razonables de escultura», vid. PoNz, Antonio: Viaje de España. Madrid, 1988 (ed. facs., 3. ${ }^{a}$ ed. Madrid 1787) vol. 2, t. vII, p. 363. Se sabe que tras el incendio de 1822 que destruyó la iglesia, entre los objetos trasladados a la parroquia de Santa María estaba el retablo mayor con el cuadro de Ruiz de la Iglesia, siendo el marco dorado que lo rodeaba parte de ese retablo, vid. CONDE DE CEDillo, López de Ayala-Álvarez de Toledo: Catálogo monumental de la Provincia de Toledo. Toledo, 1959, p. 50. Sin duda, el retablo en sí sufriría definitivos destrozos en 1936 dentro de la iglesia parroquial de Santa María, subsistiendo el gran lienzo enmarcado que mide $830 \times 380 \mathrm{~cm}$. 


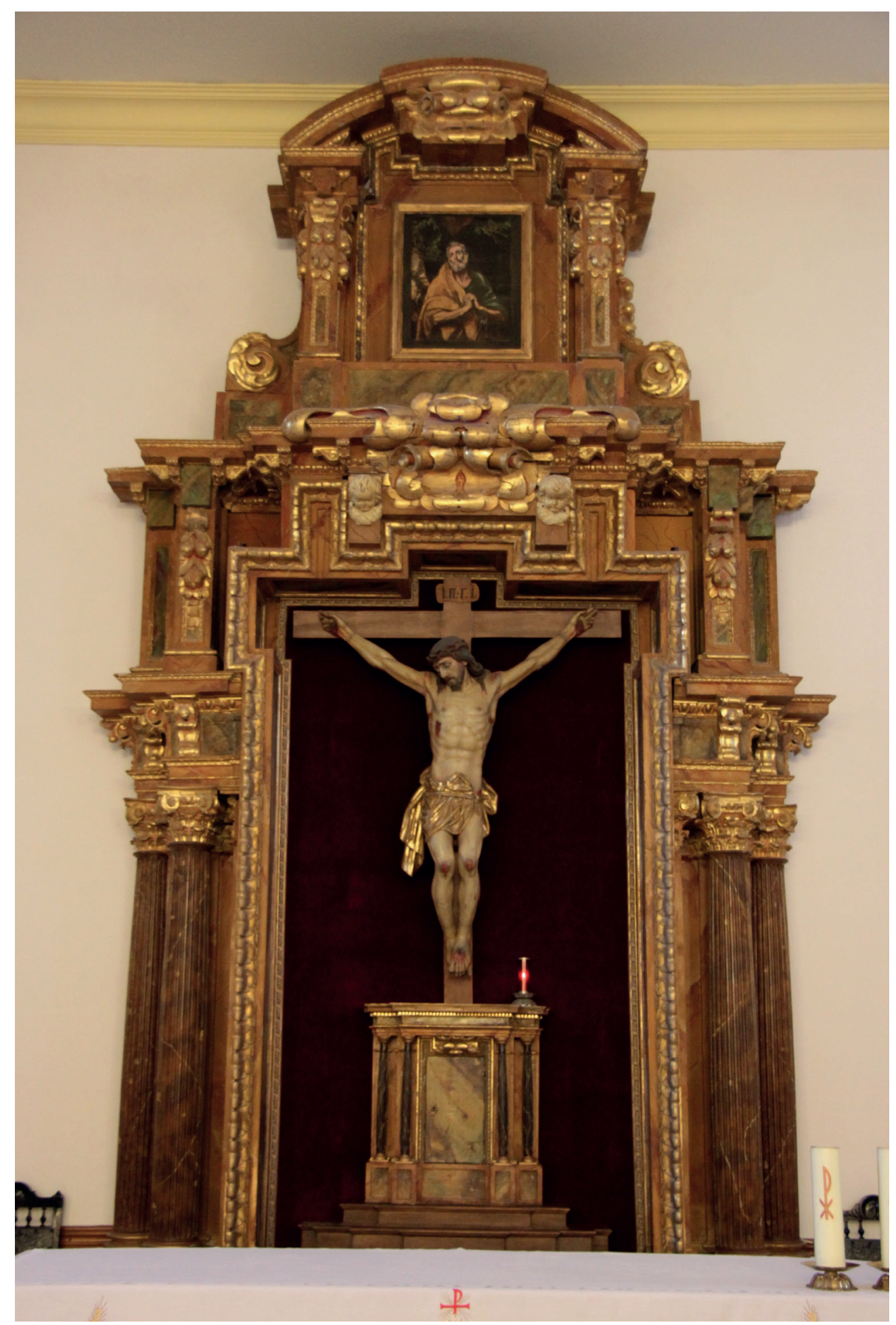

FIGURA 2. ALZADO DEL RETABLO «MAYOR》

Nambroca (Toledo). Iglesia parroquial. 
su territorio como consecuencia de asiduas visitas facultativas, requerido por su reconocida celebridad como artista. No sin hacer constar primeramente que ya en 24 de mayo de I633 este arquitecto vecino de Madrid se hallaba inscrito en el Libro de Oficiales al servicio del arzobispado, ingreso que le reconocía y facultaba como artífice aprobado para recibir cualquier encargo religioso dentro de la amplia circunscripción diocesana, de la que Madrid era mero partido eclesiástico, y lo que le permitió cuatro años después la comisión del retablo mayor de la localidad madrileña de Pinto, todavía, como se ha visto, en forma de trabajo asociado ${ }^{20}$.

Así pues, la carencia de datos en el ámbito madrileño se compensaría con una mayor presencia de Pedro de la Torre en Toledo, a tenor de otras noticias aquí acotadas. Se da el caso de que en 9 de febrero de i638 eran encargados de fabricar la sillería para el coro de la iglesia conventual de la Trinidad Calzada de Toledo los denominados «arquitectos escultores» de la ciudad José de Ortega y Juan García de San Pedro y el maestro carpintero Diego Felipe Carrasco, con trazas del primero y tomando como modelo la sillería de San Pedro Mártir (que había sido tallada por el escultor Giraldo de Merlo a principios de la centuria), tasándose la obra en 7 de marzo de 1640 por Lorenzo Fernández de Salazar, a la sazón maestro mayor de la catedral, en nombre del convento, y por el maestro de arquitectura Juan García Escribano por parte de los artífices, quien al no poder asistir es sustituido en I4 de junio de I640 precisamente por Pedro de la Torre, maestro de arquitectura vecino de Madrid, circunstancialmente en Toledo en esa fecha y, por ahora, la primera de las estancias documentadas ${ }^{21}$. En la apreciación de la sillería, Fernández de Salazar emitía dictamen desfavorable sobre Juan García, encontrando que no tenía cumplida su parte, mientras que Pedro de la Torre aseguraba que los dos principales lo habían hecho según las condiciones. Apelando a un tercero en discordia, fue el maestro de arquitectura vecino de Madrid pero también en Toledo Juan Bautista Garrido quien inclinó la balanza hacia el parecer de Fernández de Salazar sobre el incumplimiento de García de San Pedro ${ }^{22}$.

Es también la primera coincidencia laboral documentada entre el artista madrileño y el toledano García de San Pedro (ca. 1595-†r669), que tal vez pueda confirmar un vínculo personal que pensamos se produjera con la presencia temprana en Toledo de Pedro de la Torre o con una implicación artística más precisa en esta ciudad, además de considerar la cercanía procurada por el paisanaje, ya que García

20. Gutiérrez García-Brazales, Manuel: op. cit., p. 68. El sistema de adjudicación de obras en parroquias del área metropolitana administrada por el Consejo de la Gobernación del arzobispado de Toledo pasaba por el encargo directo a distintos artífices de su aprobación y según la disciplina artística en la que eran prácticos, y tratándose de retablos se hacía intervenir a un ensamblador o arquitecto, a un escultor y a un pintor dorador.

21. SuÁrez Quevedo, Diego: Arquitectura barroca en Toledo: s. xVII. Toledo, 1990, pp. 137-138. Visita que haría recién llegado de Bilbao, donde en 16 de marzo de ese año había escriturado el retablo de Ntra. Sra. de Begoña, vid. Tovar Martín, Virginia: op. cit., p. 277.

22. Desconocemos el desenlace de este trabajo tan devaluado, aunque se hubieron de subsanar los defectos con prontitud, por cuanto en 26 de junio de 1640 Juan García de San Pedro «arquitecto y vezino desta ziudad» se daba por entregado del padre fray Fernando Ramírez, religioso del convento trinitario de la villa de Madrid y electo obispo de Panamá, de la cantidad de 1.500 reales «a quenta de mayor suma que al otorgante se le esta debiendo de lo que ynporto las sillas de coro que hiço en el monesterio de la santisima trinidad desta ziudad de toledo» (AHPT, Pr. 3120, fol. 235, e. Rodrigo A. de Hoz). Imposible juzgar los méritos del trabajo realizado al no conservarse tal sillería. 
de San Pedro era natural de Priego (Cuenca), y la comunión de una misma edad, pues ambos eran nacidos en el último lustro del siglo xvı, a lo que se añade un dato documental de i638 que revela la presumible amistad entre ellos ${ }^{23}$.

\section{INTERVENCIÓN COMO ARQUITECTO EN LA CATEDRAL}

Con mayor motivo será la reanudación de las obras de construcción de la capilla de las Reliquias, el llamado Ochavo catedralicio, situado en el eje de la capilla del Sagrario, lo que vaya a procurar el directo acercamiento de Pedro de la Torre a esta capital primada y a sus más emblemáticas empresas artísticas, conducidas por el tesón del cardenal Bartolomé Moscoso y Sandoval (I646-I665) siendo probable que Pedro de la Torre acudiera a Toledo en compañía del nuevo maestro mayor de la catedral Lorenzo Fernández de Salazar (†i643) para dictaminar sobre la obra que se proyectaba para el Ochavo en una primera visita de inspección ya a finales de $163 \mathrm{I}^{24}$. Lo cierto es que tras la referida estancia de $\mathrm{I} 640$ con motivo principal de la presentación de trazas y modelos ${ }^{25}$ la obra de cantería había sido contratada en un primer momento en 6 de septiembre de I647 por el maestro burgalés Juan de la Pedrosa, activo en Madrid y últimamente en Toledo, afianzado desde la Corte por Pedro de la Torre, Lucas González y Lucas del Valle por escritura dada en enero de I648 a su favor ${ }^{26}$. Pero tras el temprano fallecimiento de aquel cantero, lo cierto es que, ahora con fianzas de José de Villarreal, maestro mayor de las obras de esa villa y ayuda de trazador y de maestro mayor de las obras de Su Majestad, y de Jerónimo

23. Así, en 8 de junio de 1638, el maestro escultor vecino de Toledo Juan García de San Pedro y su mujer María Bautista de Villacreces otorgan conjuntamente su poder a «P. ${ }^{\circ}$ de la Torre architecto vez. ${ }^{\circ}$ de la villa de Madrid Corte del rey nuestro señor» para demandar la cantidad de 32.770 maravedíes que debían a la señora como albacea y heredera usufructuaria de su anterior marido Alonso de Lamarcha y titular de una obra pía fundada por éste y en beneficio de sus hijos; un poder «espeçialmente . $^{a} \mathrm{q}$ - en $\mathrm{nr} .^{\circ}$ nombre rrepresentando nuestras perssonas pida e demande extrajudiçialmente del Sr. Lcdo. Juan Ruiz de San Cebrian, Visitador de Madrid y su partido como albacea testamentario del que quedo de P. ${ }^{\circ}$ Sanchez del Pozo, vz. ${ }^{\circ}$ de Toledo, tutor y curador de sus hijos y herederos» (AHPT, Pr. 3256, fol. 653, e. Roque de Morales).

24. Marías, Fernando: La arquitectura del Renacimiento en Toledo (1541-1631). 4 vols., Madrid, 1983-1986, t. III, p. 207. A Fernández de Salazar se deben tres proyectos del interior del Ochavo así como un modelo en madera, estilísticamente dentro de la corriente post-herreriana.

25. En 4 de junio de 1640 Pedro de la Torre recibía en Toledo un pago de 444 reales por su ida y vuelta con dos modelos de madera del Ochavo, y luego en I de octubre del mismo año recibiendo 8.000 reales por el modelo que hizo al efecto, vid. ZaRCO DEL VALLE, Manuel R.: op. cit., p. 330.

26. No dejemos de lado la efectiva intervención del hermano Francisco Bautista en el trazado de la obra puesto que ya en 12 de agosto de 1647 recibía 100 ducados de vellón por su viaje desde Madrid a «ajustar la traza y disposicion con que se a de executar la obra de esta Sta. Iglesia que llaman del ochavo de las reliquias de ella», también Pedro de la Torre recibía 37.500 maravedíes por lo mismo, y Juan de la Torre, tracista, otros 50 ducados por «trazar y dibuxar lo que se a de executar en la obra del ochabo con el Pe. Bautista y P. ${ }^{\circ}$ de la Torre», vid. ZARCO DEL VALLE, Manuel R.: op. cit., p. 333; en competencia con las trazas dadas por el maestro mayor Felipe Lázaro Goiti, vid. MARÍAS, Fernando: op. cit., t. III, pp. 207-209. No era ésta la primera ocupación edilicia en la carrera de Pedro de la Torre, puesto que conocemos que en 1642 ya había proporcionado los planos aprobados para la edificación de la capilla de San Isidro en la iglesia de San Andrés de Madrid, obra que sin embargo se ralentizó hasta coger nuevo impulso en 1657 bajo dirección de José de Villarreal, vid. Tovar MARTín, Virginia: op. cit., p. 267. Las pretensiones de arquitectos artistas frente a arquitectos constructores forman parte de una controversia sobre competencias profesionales no resuelta a lo largo del siglo XVII, vid. BLASCO ESQUIVIAS, Beatriz: «Sobre el debate entre arquitectos profesionales y arquitectos artistas en el barroco madrileño. Las posturas de Herrera, Olmo, Donoso y Ardemans», Espacio, Tiempo y Forma, Serie VII, H. ${ }^{a}$ del Arte, 17 (2004), pp. 159-194. 


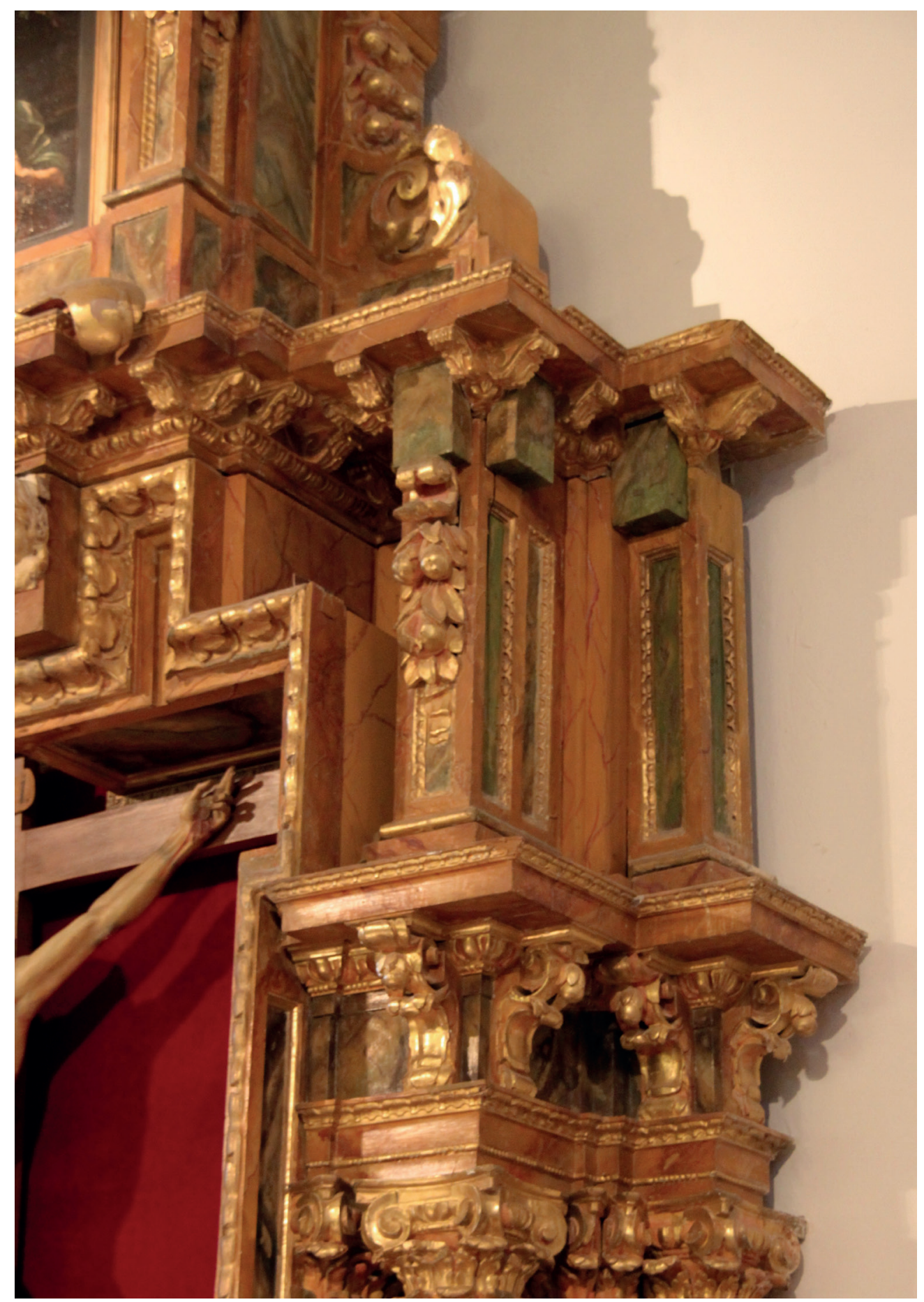

FIGURA 3. DETALLE DEL ORDEN COMPUESTO

Nambroca (Toledo). Iglesia parroquial. Retablo «mayor». 
Lázaro (Goiti), maestro de obras y alarife de Madrid, y por el poder otorgado por éstos en la capital del reino ante el escribano Gil López de Santa María, se presentaba en Toledo en I3 de agosto de I648 Pedro de la Torre «maestro de arquitectura» y vecino de la villa de Madrid como uno de los fiadores del difunto Juan de la Pedrosa, para otorgar la nueva escritura de obligación y continuación de las obras, comprometiéndose al día siguiente con el cantero Juan de la Fuente, yerno y heredero de Pedrosa, a firmar un convenio de atribuciones en dicha obra ${ }^{27}$. Tras un acuerdo tácito en la rebaja de real y medio en los precios de la cantería, en 20 de mayo de I649 el canónigo Obrero Mayor don Pedro López de Inarra Isasi, reconociendo «quan gran artifiçe es el dho pedro de la torre y la berdad y puntualidad conque a cumplido y se espera cunplir con quanto le toca de su parte sin faltar en cosa alguna», acepta la pactada revisión económica con Pedro de la Torre a fin de no prescindir de él, y agradecido éste de la decisión del canónigo de mantenerle en la adjudicación de la obra frente a ofertas ventajosas de otros maestros que se hubieran presentado a concurso ${ }^{28}$.

Pero no es hasta el 9 de septiembre de I65o que de nuevo en Toledo Pedro de la Torre junto con el socio cantero hacían definitivo ajuste y nombraban tasadores para valorar lo dejado hecho por Juan de la Pedrosa; y a partir de aquí hacer compañía, él como encargado de la obra de la capilla de las Reliquias y Juan de la Fuente como realizador material de la misma, cediendo a éste la cuarta parte del negocio a pérdidas y ganancias ${ }^{29}$. Con la obra de cantería en su etapa final, el Cardenal llamaba en noviembre de 1652 al maestro mayor de la Santa Iglesia de Jaén Juan de Aranda Salazar y en diciembre le convocaba en junta de arquitectos para dictaminar en lo referente a la obra del Ochavo, a la que asistieron el maestro mayor de las obras del palacio de Madrid, José de Villarreal, y el también maestro mayor de palacio Alonso Carbonell ${ }^{30}$ y es en 25 de abril de 1653 cuando Pedro de la Torre vuelve a Toledo con

27. AHPT, Pr. 104, fol. 707, e. Rodrigo A. de Hoz. Además, Pedro de la Torre recibía ya 400 reales en 14 de agosto de 1648, por mano del cantero Marcos Dulset, su poderhabiente en la obra (Archivo Catedral de Toledo (ACT), Libro de Frutos 1648, fol. 112) y en 21 de octubre de ese año se le libran personalmente 1.000 reales por la obra de cantería «por quanto abiendo benido de M[adri]d. a la disposicion de las molduras y compartimento de la cornisa y principio de la $\mathrm{m}^{\mathrm{a}}$ naranja en que se ocupo tres semanas en esta ciudad y a echo un modelo para $\mathrm{q}^{\wedge}$. conforme del labren las canteras» (Idem, fol. 113).

28. AHPT, Pr. 3140, fol. 42 y 702, e. Rodrigo A. de Hoz. En 1649 Pedro de la Torre se hallaba en Madrid ocupado, entre otras obras, en la capilla de Ntra. Sra. de Atocha del convento de dominicos; esto es así, que en el capítulo ordinario del ayuntamiento de Toledo de 8 de marzo se abrió una petición de don Francisco de Prado Bravo, secretario de S.M. de Obras y Bosques, por la que con motivo de que el rey había ordenado hacer un retablo en el real convento de Ntra. Sra. de Atocha de Madrid que sea de piedra de diferentes partes y entre ellas de la cantera de San Pablo de los Montes, jurisdicción de Toledo, se solicitaba al corregidor toledano Bernardino de Meneses la oportuna licencia para la saca, acordándose «que de la cantera del lug- de San Pablo se corten y saquen por Pedro de la Torre mill y quinientos pies cubicos de la piedra de la dha cantera q- son los que a entendido la ciudad seran menester para dho retablo...» Archivo Municipal de Toledo (AMT), Libro Capitular Año 1649, n. ${ }^{\circ}$ 69, s/f.

29. AHPT, Pr. 3602 , fol. 590 y ss., e. Alonso Sánchez de Mora. Es testigo del acto Juan García de San Pedro. Año en que Alonso Cano llega a Toledo requerido por el Cardenal.

30. Zarco del Valle, Manuel R.: op. cit., p. 92. Varios son los pagos a Pedro de la Torre en 1652, unos en mano en 14 de junio y 24 de agosto y otros en su nombre cobrados por el cantero Marcos Dulset y por Juan García de San Pedro «por letra y qt. ${ }^{a}$ de Pedro de la Torre de lo que a de aber de su encargo de la obra del ochavo que va con su libranza y son por qt. $^{a}$ del dicho P. ${ }^{\circ}$ de la torre», y también dados al cantero Juan de la Fuente, vid. MARíAs, Fernando: op. cit., t. III, p. 209. Carbonell aprobaría en Madrid, en 12 de octubre de 1652, una traza del interior del Ochavo realizada por Pedro de la Torre. 
el propósito de nombrar tasador para la obra ya concluida del Ochavo, por lo que el Obrero Mayor López de Inarra, por una parte, y por la otra, Pedro de la Torre, arquitecto vecino de Madrid, y Juan de la Fuente, maestro de cantería de Toledo, eligen y nombran de común acuerdo a Felipe Lázaro Goiti, arquitecto y maestro mayor de obras de la Santa Iglesia y de los Reales Alcázares desde I643, para medir la obra que había corrido por cuenta de ambos maestros ${ }^{31}$.

Y, desde luego, Pedro de la Torre ya había mantenido inevitable relación profesional en esos años con Lázaro Goiti (†1653) para dirimir cuestiones técnicas y presentar trazas y dibujos para el edificio ${ }^{32}$. Incluso Pedro de la Torre le había otorgado en Toledo en ro de septiembre de i650 un poder para que en su nombre se obligase a favor del notable toledano don Gonzalo Hurtado de Herrera a la obra de un retablo, con las condiciones precisas y otorgando las escrituras necesarias, asistiendo como testigo a este acto protocolario el ensamblador Juan García de San Pedro ${ }^{33}$. Así mismo, en las nuevas ocupaciones catedralicias, las del ornato interior del Ochavo, se fraguó la estrecha colaboración entre su diseñador Pedro de la Torre y Bartolomé Sombigo y Salcedo (†ı683), el especializado arquitecto y tracista toledano encargado del revestimiento marmóreo desde i654, en la ocasión de ciertas obras madrileñas conjuntas y el envío de remesas de mármol de las canteras del municipio toledano de San Pablo de los Montes a la villa de Madrid ${ }^{34}$.

31. AнPT, Pr. 3152, fol. 610, e. Rodrigo A. de Hoz.

32. Para ver estos dibujos ya publicados por Fernando Marías en su obra referida, Fernández ColLado, Ángel, Rodríguez González, Alfredo \& Castañeda Tordera, Isidoro: Los diseños de la catedral de Toledo. Toledo, 2009, pp. 144-146.

33. AHPT, Pr. 3602 , fol. 601, e. Alonso Sánchez de Mora. Escritura que no tuvo efecto inmediato, pues el contrato definitivo tendría lugar en 1652 .

34. En síntesis, podemos citar tres documentos protocolizados en Toledo que atestiguan esta asociación laboral: a) un poder que le otorga en 20 de febrero de 1657 Bartolomé Sombigo, «maestro arquitecto residente en esta ciudad de Toledo», para cobrar de Alonso de Mellado los 500 ducados que le corresponden y para ello dé carta de pago, en razón de que Pedro de la Torre, maestro arquitecto vecino de la villa de Madrid, y él se obligaron «que ariamos la obra y fabrica que se a de açer en el convento de monxas de santo domingo el rreal de la dha villa para poner los cuerpos de los señores rrey don Pedro y ynfante don Juan en conformidad y segun el ajustamiento planta y traça condiciones y obligazion de la escritura que se otorgo ante [entre renglones: Pedro de Soto] escribano en ocho deste mes y año», y por haberse librado a cuenta dos pagos de 500 ducados cada uno (AHPT, Pr. 3662, fol. 13, e. Francisco Tovar); b) una carta de pago de 13 de marzo de 1657 por la que Sombigo en nombre de Pedro de la Torre, maestro arquitecto vecino de Madrid (usando del poder dado en Madrid en 16 de febrero de 1657, ante Pedro de Soto), recibe de Francisco de Adrada, depositario de los dineros del servicio a S.M., 500 ducados en cuenta de lo que han de hacer en la iglesia de Santo Domingo de Madrid en la obra de los enterramientos reales (AHPT, Pr. 212, fol. 73, e. Francisco Álvarez de Soto); c) una carta de pago de 4 de febrero de 1659 dada por Bartolomé Sombigo «ayudantte de aparexador de las obras Reales y vezino desta çiudad en nombre de Pedro de la Torre Maestro de arquittettura Vezino de la villa de Madrid y por su poder ottorgado en dha villa en veyntte y siette de abril del año passado de mill y seiszienttos y cinquenta y ocho ante Domingo Zid scn. ${ }^{\circ}$ del Rey nro Sr...», otorgando haber recibido de Antón Pérez, sacador de piedra, 78,5 pies cúbicos de mármol de San Pablo de los Montes, a lo que se obligó «por scriptura que en su favor ottorgo para el Rettablo de Attocha y obra de Santtiago de Madrid», una en el lugar de las Ventas con Peña Aguilera de 12 de marzo de 1649 ante el escribano del lugar Alonso Martín de Ángel, y la otra en el lugar de San Pablo de 15 de marzo de 1649 ante el escribano Pedro Sánchez Valero, con lo que se acababa de ajustar, pagar y entregar toda la piedra prevenida (AHPT, Pr. 3465, fol. 146, e. Diego Verde). 


\section{LA LABOR CREATIVA Y EL MODELO DE TRONO}

Al mismo tiempo que la empresa edilicia de concepción barroca concentrada en la octogonal capilla relicario ${ }^{35}$ se pretendía la erección en la misma catedral de Toledo y en su contigua capilla del Sagrario de un magnífico trono de plata para la emblemática imagen de la Virgen, cuyos preparativos y resolución se espació entre I647 y I655. Ampliamente estudiado ${ }^{36}$, el proyecto se inicia con un primer diseño o traza presentada al cabildo catedralicio por el platero madrileño Joaquín de Pallarés ya en junio de I647, pero al maestro de arquitectura de Madrid Pedro de la Torre se le pagaban I.650 reales de vellón en 28 de diciembre de ese año por «acer la traça y dibuxo del santuario o trono de nuestra señora del sagrario» ${ }^{37}$. Tras un primer encargo de platería fallido en I648, se hubo de abrir un concurso de ideas para la discusión del propio diseño, siendo Pedro de la Torre quien finalmente asume el encargo de este trono-baldaquino para la Virgen del Sagrario, en oposición a la traza presentada por Sebastián de Herrera Barnuevo y su colega Alonso Cano, pero resultando modificado el arco de columnas clásicas propuesto por aquél al cambiarse al tipo salomónico, a sugerencia quizás del artista granadino, a quien desde luego se le libran I.00o reales en I7 de marzo de 1650 «por los pareceres y trazas que dexo en orden a las obras del Sagrario ${ }^{38}$. Ante esta solución compartida, un modelo en madera habrá de servir al platero Virgilio Fanelli a quien, en el contrato definitivo de 8 de enero de I655, entre las condiciones estipuladas para su ejecución, se le permitía primeramente hacer la obra del trono,

con ynterbencion y compañia de Francisco de Salinas platero de dha sancta yglesia vecino de esta ciud. segun el disinio que esta elexido en un modelo de madera que se les a mostrado y ellos bisto y rreconocido mudando de el o añadiendo aquello que paresçiere ser mas combeniente y mexoren su verdadero tamaño segun se dira en la condicion subsiguiente. $2 .^{\circ}-$ Que el dho artifiçe aya de linear el dho desinio en un ta-

blero, o lienço en el tamano que a de tener en la exsecuçion que se a axustado a las

35. SuÁrez Quevedo, Diego: op. cit., pp. 255-257.

36. Por orden cronológico: Abel Vilela, Adolfo de: «Pedro de la Torre y los retablos baldaquino de la Virgen del Sagrario de Toledo y de los Ojos Grandes de Lugo», Espacio, Tiempo y Forma, Serie vil, H. ${ }^{a}$ del Arte, 8 (1995), pp. 145-166; Nicolau CAStro, Juan: «La maqueta del trono de la Virgen de Sagrario de la Catedral de Toledo», Academia: Boletín de la Real Academia de Bellas Artes de San Fernando, 83 (1996), pp. 271-286; y MARías, Fernando: «Alonso Cano y la columna salomónica», en Figuras e imágenes del Barroco. Estudios sobre el barroco español y sobre la obra de Alonso Cano. Madrid, 1999, pp. 291-322.

37. Zarco del Valle, Manuel R.: op. cit., p. 333. Antes, en 28 de junio de 1647 se libraban a Joaquín Pallares, platero de Madrid, 17.000 mrs «por su biaje a Md- que bino llamado y truxo unas trazas para el trono de Nuestra Sr. ${ }^{a}$ del Sagrario», vid. Nicolau Castro, Juan: op. cit., p. 275.

38. Zarco del VAlle, Manuel R.: op. cit., p. 354. El dibujo, dos grabados y la maqueta se conservan. Se supone que una traza rechazada de Pedro de la Torre sirvió de modelo del trono de la Virgen lucense en 1655, que también cambió las columnas rectas por salomónicas, vid. ABEL VILELA, Adolfo: op. cit., p. 158-16o. Bien pudo Alonso Cano corregir el diseño de su socio Herrera y ser el que dibujó una media traza con columna salomónica, que conserva el mismo archivo de Obra y Fábrica, vid. MARíAs, Fernando: «Alonso Cano y la columna...», pp. 301-303. El pago también de ciertas estampas trabajadas por el platero madrileño Juan Ortiz que se enviaron a Roma «con cien papeles de colunas salomonicas» y de la pintura del trono de Ntra. Sra. que hizo el pintor Miguel Vicente para enviar a Roma igualmente, indican la inclinación del Cardenal por el orden salomónico; y en 14 junio de 1657 se libran al pintor y arquitecto madrileño Juan de Gandía 100 reales de plata por la ocupación de venir de Madrid nombrado por parte de la Obra para tasar «la traza y dibujo en grande del trono de Nra Sra», vid. Nicolau CaStro, Juan: op. cit., p. 277. 
medidas de el sitio en que esta la sancta ymagen dexando los guecos combenientes para mayor desaogo de la obra y serbiçio de la sancta ymagen - y en esta traza a de poner todos aquellos adornos en que se ubiere de mexorar el modelo y en particular, a de dibuxar las columnas que sean salomonicas y rrebestidas de oxas... ${ }^{39}$

Únicamente se hicieron dos trazas para el trono, a tenor del posterior documento de pago de 200 reales que se liquidaron en I4 de febrero de I655 a Sebastián de Herrera, vecino de Madrid, por «hazer una traza para el trono de nuestra señora en oposicion de la que hiçieron Pedro de la Torre y el padre Baptista» ${ }^{40}$ y que sería la elegida y de inmediato plasmada por el grabador flamenco en Madrid Juan Noort en unas primeras estampas de i649 y i650 que de este trono de columnas aún rectas se tiraron para divulgación gráfica de lo que llegaría a ser aquella obra de la que hoy se conserva asimismo la bella maqueta que sirvió de modelo general y labrada igualmente por Pedro de la Torre entre 1652 y I $655^{4 \mathrm{I}}$.

\section{LOS RETABLOS TOLEDANOS DE PEDRO DE LA TORRE}

A la vez que solicitado en la catedral toledana es igualmente revelador el dato que señala a Pedro de la Torre como autor del desaparecido retablo mayor de la iglesia de Santo Tomás de Orgaz, pues a esta villa pasaba ya en 22 de marzo de 1649 este maestro de arquitectura y vecino de Madrid para otorgar carta de pago y entrega por el mayordomo de aquella parroquia del finiquito de i.roo reales de vellón por «la traza del rretablo que se a de azer en la yglesia desta billa y venir desde la dha $v{ }^{a}$ de madrid a la de orgaz tres bezes» ${ }^{42}$. Asegurado el diseño, el maestro de arquitectura y vecino de Toledo Juan García de San Pedro acude en 3i de marzo de i653 a Orgaz para contratar la obra del retablo mayor, con la condición expresa de que se obedezcan las trazas del «P..$^{\mathrm{e}}$ Franc. ${ }^{\circ}$ Bautista de la conpañia de Jesus y $\mathrm{P}^{\circ}$ de la torre maestros de arquitetura v. ${ }^{\text {os }}$ de md.», en precio de 28.500 reales y dos años para su ejecución, con lo que la entalladura y ensamblaje quedaba en manos del artista toledano y su taller, requiriéndose en I655 para hacer las pinturas a Francisco

39. AHPT, Pr. 3156, 1655, fol. 94, e. Rodrigo A. de Hoz. A ésta sigue, en el mismo día, la escritura de obligación de compañía entre ambos artífices, cuya primera cláusula dice que «el dho Franc. ${ }^{\circ}$ de Salinas a de labrar y fabricar en el dho trono todo aquello que declarare Pedro de la Torre arquitecto y beçino de la dha Villa de Madrid...», en quien recae toda la dirección.

40. Zarco del Valle, Manuel R.: op. cit., p. 338. Es cierto que el Hermano Bautista sería coautor de las trazas presentadas por Pedro de la Torre.

41. Nicolau Castro, Juan: op. cit., pp. 276-278. Marías, Fernando: «Alonso Cano y la columna...», pp. 299301. Sin ninguna duda, el modelo en madera presentado al platero italiano es el conservado en el Museo catedralicio, atribuido erróneamente a Herrera Barnuevo, pero compuesto de columnas corintias. Una vez elegido el dibujo de Pedro de la Torre, el modelo en madera pasó por el vestuario o sacristía de la capilla del Sagrario sirviendo a su vez de trono a una imagencilla de la Concepción y colocado dentro de un retablo barroco realizado ex profeso en 1711 por el ensamblador Andrés de Huerta, no sin que antes aderezara el pequeño trono el escultor Antonio Fernández, vid. Zarco del Valle, Manuel R.: op. cit., p. 387.

42. AHPT, Pr. 11954, s/f., e. Diego Sainz de Espinal. En concreto, se especifican 230 reales recibidos del anterior mayordomo más los 870 que se le entregaban de presente. 


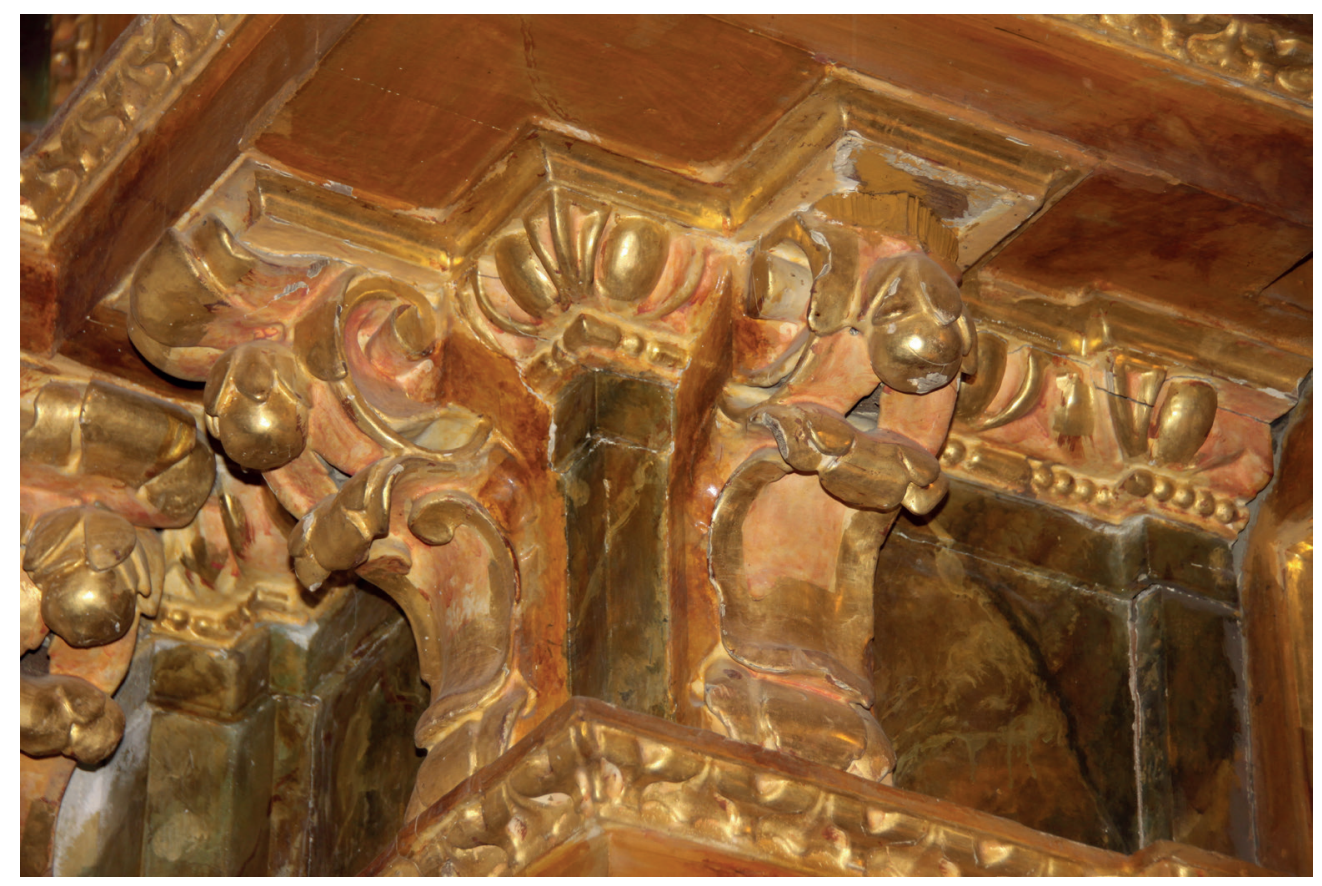

FIGURA 4. DETALLE DEL ENTABLAMENTO DE MODILLONES Nambroca (Toledo). Iglesia parroquial. Retablo «mayor».

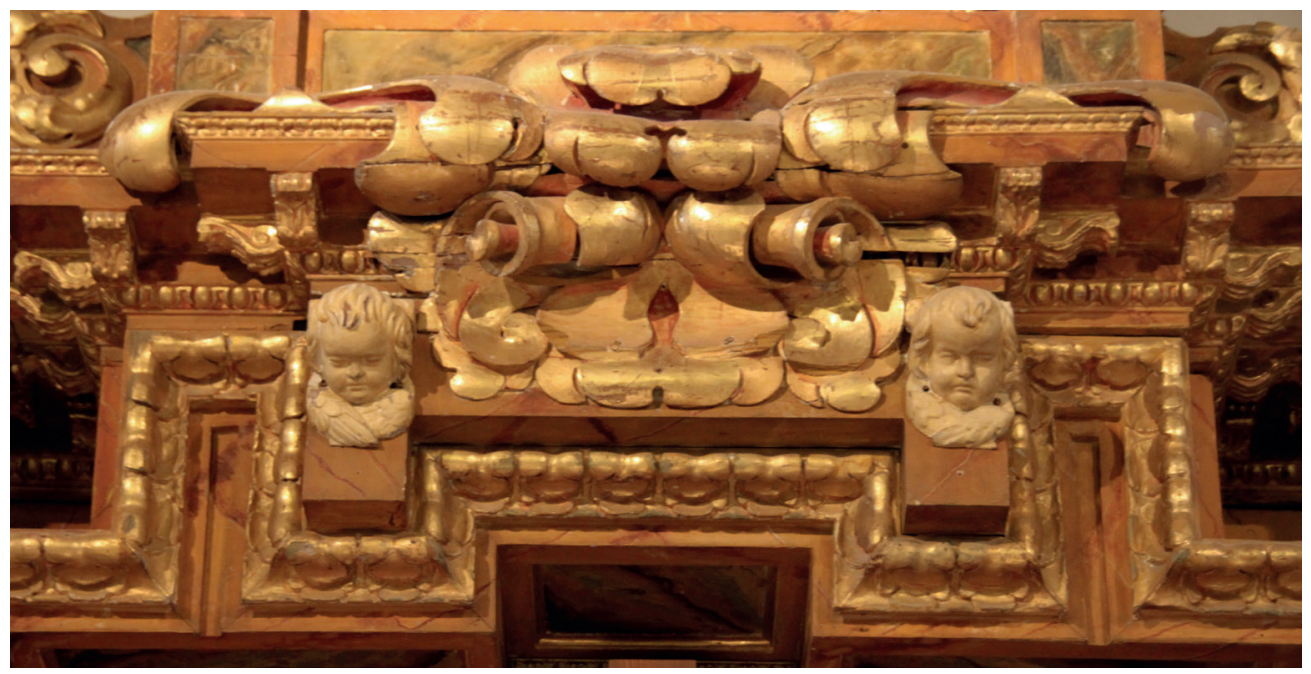

FIGURA 5. DETALLE DE LA TARJETA PRINCIPAL

Nambroca (Toledo). Iglesia parroquia. Retablo «mayor». 
$\operatorname{Rizi}^{43}$, que ya ostentaba el título de pintor mayor de la catedral desde junio de I653 sucediendo al pintor y dorador toledano Antonio Rubio ${ }^{44}$.

Es más adelante, en I5 de julio de I659, cuando Pedro de la Torre se halla en Toledo para ajustar y liquidar lo que se le debía por todos los trabajos realizados hasta la fecha para el cabildo catedralicio como "mro de arquitecto $\mathrm{y} \mathrm{vz} .^{\circ}$ de la V..$^{\mathrm{a}}$ de Madrid y a cuyo cargo a estado la obra esterior del ochavo desta Santa Yglesia y de las demas de el modelo del trono que se fabrica para la Santa Ymagen del Sagrario y traças que a hecho p. ${ }^{a}$ la dicha Santa Yglesia», siendo uno de los testigos del acto notarial su colaborador en la ciudad Juan García de San Pedro ${ }^{45}$. Estas regulares estancias en Toledo entre I647 y I659 confirman la implicación de Pedro de la Torre en los proyectos aquí reseñados y prueban su solvente autoridad en el medio artístico toledano, en el que también la pequeña oligarquía local es cliente ocasional como en el caso del retablo hasta ahora inédito que pretendemos documentar e identificar.

Por tanto, la obra en cuestión es la que reconocemos por su primitiva ubicación en la iglesia conventual de la Trinidad Calzada de Toledo e identificada como retablo del Santo Cristo, obra hoy descontextualizada de su espacio original y enclavado

43. AHPT, Pr. 11939, (1653) fol. 121, e. Alfonso Moreno. Aunque las trazas estaban dadas por los socios arquitectos en 1649 la ejecución no se emprendió hasta 1653. NiCOLAU CASTRO, Juan: «El desaparecido retablo de la parroquial de la villa de Orgaz y sus pinturas de Francisco Rizi», en In Sapientia Libertas: Escritos en homenaje al profesor Alfonso E. Pérez Sánchez. Madrid/Sevilla, 2008, pp. 471-474. El retablo mayor, desaparecido en 1936, se conoce a través de fotografía, revelando una inscripción que esta obra se terminó de dorar en 1662, siendo cura propio el Dr. D. Francisco de Contreras, vid. CONDE DE Cedillo: op. cit., pp. 228-229, n. ${ }^{\circ} 309$, il. CIII.

44. Céán Bermúdez, Juan Agustín: Diccionario histórico de los más ilustres profesores de las Bellas Artes en España. Madrid, 1965 (ed. facs. Madrid 1800), t. IV, p. 204.

45. Nicolau Castro, Juan: «La maqueta del trono...», p. 278. Zarco del Valle, Manuel R.: op. cit., p. 339. La escritura original comienza: «En la ciudad de Toledo quinçe dias deel mes de julio mil seiscientos y cinquenta y nueve años Parecio ante mi el escrivano y testigos $P .{ }^{\circ}$ de la Torre mro. de arquitecto y $V z .^{\circ}$ de la $V .^{a}$ de Madrid y a cuyo cargo a estado la obra esterior del ochavo desta Santa Yglesia y de las demas de el modelo del trono que se

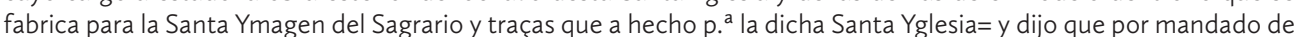
el em. ${ }^{\circ}$ sr. cardenal arçovispo de Toledo don Baltasar de Moscoso y Sandoval mi Sr. se a ajustado la quenta de todo lo que an ynportado los dhos encargos y traças y otro genero de cosas hasta oy con yntervencion de los señores don P. ${ }^{a}$ Lopez de Ynarra Ysasi Dignidad y canonigo y obrero mayor de la obra y fabrica de dha Santa Yglesia= don Antonio de Ysla y don Antonio Castañon asimismo canonigos y visitadores deella y della Resulta de alcance a favor del dho P..$^{\circ}$ de la Torre $=$ doze mil novecientos y sesenta y seis Rs y tres quartillos vellon cuya cantidad el dho Sr. obrero $\mathrm{m}^{\circ} \mathrm{r}$ le tiene consignados y librados en Lucas de Olarte Receptor Jeneral dela dha obra y fabrica y asi consta de dha quenta y librança...». Y acusa en concreto dos partidas de gastos, una de 30.000 reales «por las traças que para la dha obra de canteria hiço y para las del trono de nra S. ${ }^{a}$ su estanpa y modelo de madera y otras traças para los jaspes del ynterior de dha cap. ${ }^{a}$ cuyos precios tasaron el padre franc. ${ }^{\circ}$ bautista y Joseph de ortega mro $\mathrm{m}^{\circ} \mathrm{r}$ desta Santa ygle. ${ }^{\mathrm{a}}$ como parece por su declaracion de quatro de abril de mil seis ${ }^{\circ}$ s y cinq. ${ }^{a}$ y quatro años» más otra de 24.000 reales para satisfacer y pagar a «P. $^{\circ}$ de la Torre de todas sus obras y pretensiones hasta oy dho dia y en especial de los ochocientos ducados en que se taso por declaracion de mros ante mi el dho ssn. ${ }^{\circ}$ en trece de junio del año pasado de mil seis ${ }^{\circ}$ s y cinqt. ${ }^{a}$ y siete la traça en grande del trono de nra S. ${ }^{a}$ que esta ejecutando Birjilio Faneli arquitecto y aunque el dho Birjilio Faneli por su escritura se encargo de dha traça por no haver dado satisfacion della la da aora la dha fabrica en esta partida», siendo testigo con otros vecinos de Toledo Juan Garcia de San Pedro (AHPT, Pr. 3167, fols. 778-779v, e. Rodrigo A. de Hoz). Antes, en 5 de marzo de 1659, en carta de pago dada en Toledo por Bartolomé Sombigo y Salcedo, actuando en nombre de Pedro de la Torre, maestro de arquitectura de Madrid, (por el poder otorgado en esa villa ante el escribano Domingo Cid en 27 de abril de 1658), se da por recibido de Alfonsa García, vecina de Ventas con Peña Aguilera y viuda heredera de Lucas de Urosa, sacador de piedra mármol de San Pablo, de 107 pies cúbicos de mármol de dicha cantera, los que quedó debiendo a su parte y como persona que sucedió a Juan de la Pedrosa, vecino que fue de Madrid, con los que se acaban de ajustar las escrituras y contratos otorgados, la una de 500 pies cúbicos dada en Ventas con Peña Aguilera ante Alonso Martín de Ángel en 12 de marzo de 1649 , la otra por 500 pies cúbicos dada en San Pablo en 15 de marzo de 1649 ante Pedro Sánchez Valero, más otra dada en Madrid a 7 de abril de 1650 ante Julio Pérez Santa María (AHPT, Pr. 3465, fol. 226, e. Diego Verde). 
en otro templo rural próximo a la capital ${ }^{46}$. En el documento que damos a conocer, de fecha I6 de agosto de I652, comparecen en Toledo Pedro de la Torre, vecino de la villa de Madrid, y Juan García de San Pedro, vecino de Toledo, «como maestros en arquitectura», obligándose ambos de mancomún a favor del jurado de la ciudad don Gonzalo Hurtado de hacer un retablo en blanco junto al altar mayor de la iglesia conventual de la Trinidad Calzada de esta ciudad en precio de 8.500 reales de vellón, en madera de pino de Cuenca y con una custodia de cuatro columnas, para asentarlo en el plazo de un año ${ }^{47}$ (Documento Anexo). Recordamos que Pedro de la Torre proyectaba este retablo en tanto permanecía ocupado en la dirección de la obra final de cantería del Ochavo y en la determinación de su ornato interior a la vez que en las trazas y realización de la maqueta del trono de Ntra. Sra. del Sagrario, mientras que Juan García de San Pedro lo terminaría en el plazo señalado de un año, hacia agosto de I653, cuando ya había asumido la obra del gran retablo mayor de la parroquia de Orgaz, contratado cinco meses atrás ${ }^{48}$.

Una vez erigido y situado de manera un tanto provisional en un pilar del evangelio debido a las obras en curso dentro del edificio trinitario, lo cierto es que en I3 de agosto de 1672 se convino trasladar el altar con su retablo del Santo Cristo a la nueva capilla colateral abierta en el lado del Evangelio, una vez acabada la obra de crucero y capilla mayor, que era cedida por la comunidad de religiosos al entonces regidor y caballero de Santiago don Gonzalo Hurtado de Arteaga, sucesor en esta rama del linaje de los Hurtado y en la fundación de memorias de su inmediato antecesor ${ }^{49}$. El retablo permaneció presidiendo su capilla independiente durante todo

46. Antes de su traslado se describía de este modo: «En la capilla colateral a la capilla mayor encontramos un retablo de estilo barroco, en madera pintada imitando mármol, con columnas estriadas y capiteles corintios; a su izquierda y derecha un escudo; en el centro un Cristo de tamaño natural, atribuible a Castañeda, y en el remate, un nicho cuadrado entre dos pilastras. La decoración es a base de molduras vegetales talladas y doradas», vid. REVUELTA Tubino, Matilde (dir.): Inventario Artístico de Toledo Capital. Madrid, 1983, pp. 282-283. En 1981 con la desacralización del templo, que pasa a propiedad municipal, y su desmantelamiento se dispersa el vasto patrimonio mueble en distintos edificios religiosos de la diócesis toledana. Y esto sucedió con el retablo aquí documentado, que no había que considerar perdido pues se confirma que el actual retablo «mayor» de la parroquia de Ntra. Sra. de la Purificación de Nambroca (Toledo) procede de San Marcos; información que agradezco a Pablo Delclaux, Delegado de Patrimonio, y a su párroco D. Román Aguado Mancebo, la posibilidad de su estudio.

47. АНРт, Pr. 3404, fols. 459-46ov, e. Alonso de Galdo.

48. Sobre el arquitecto de retablos Juan García de San Pedro, su biografía y obras en Díaz Fernández, Antonio José: El retablo barroco en Toledo (1632-1732). (Tesis doctoral inédita), UNED, 2012. Bajo la dirección del Dr. D. Víctor Nieto Alcaide esta tesis fue leída en 30 de mayo de 2012, en la Facultad de Geografía e Historia de la Universidad Nacional de Educación a Distancia, Departamento de Historia del Arte. Obra inmediatamente anterior al retablo aquí documentado es el retablo mayor de la parroquia de San Cebrián de Toledo (1649-52) cuya traza se ajusta al modelo escurialense compartimentado y desornamentado, vid. DíAz FERNÁNDEZ, Antonio José: «En torno al proceso de caracterización...», pp. 106-107. Y poca obra posterior por él trazada ha perdurado.

49. AHPT, Pr. 179, fol. 156, e. Eugenio de Valladolid. Esta capilla definitiva, que culmina la fundación de don Alonso Hurtado del Âguila, se construía a principios del s. XVIII, según el encargo de obra firmado en 17 de octubre de 1705 entre don Rafael Hurtado de Herrera, hijo y sucesor en el patronato de su padre Gonzalo Hurtado, y los maestros de obras Ignacio de Arias, maestro de carpintería, y el alarife de la ciudad Juan Díaz Aldeano, maestro de albañilería, obedeciendo traza y condiciones del entonces maestro mayor de obras de los Reales Alcázares Pedro González en precio de 11.500 reales, tratándose de levantar la cúpula de la capilla sobre un ochavo, el cañón de bóveda, la pequeña sacristía y tribuna (AHPT, Pr. 3951, fol. 738, e. Juan Gómez Marcote). Con la cesión los religiosos trinitarios agradecían al regidor su ayuda al convento «donde tienen su capilla y bobeda para su entierro fundando diferentes memorias y capellanias, de que el convt. ${ }^{\circ}$ goza en su sacristia diferentes utilidades y continuando su devocion para la obra de la capilla maior que se esta haciendo en dho convt. ${ }^{\circ}$ a dado el agua necesaria de los poços de su casa q- es contigua a dicha capilla maior y a de continuar el darla y a ayudado con sus cavalgaduras y criados a traher piedra y 


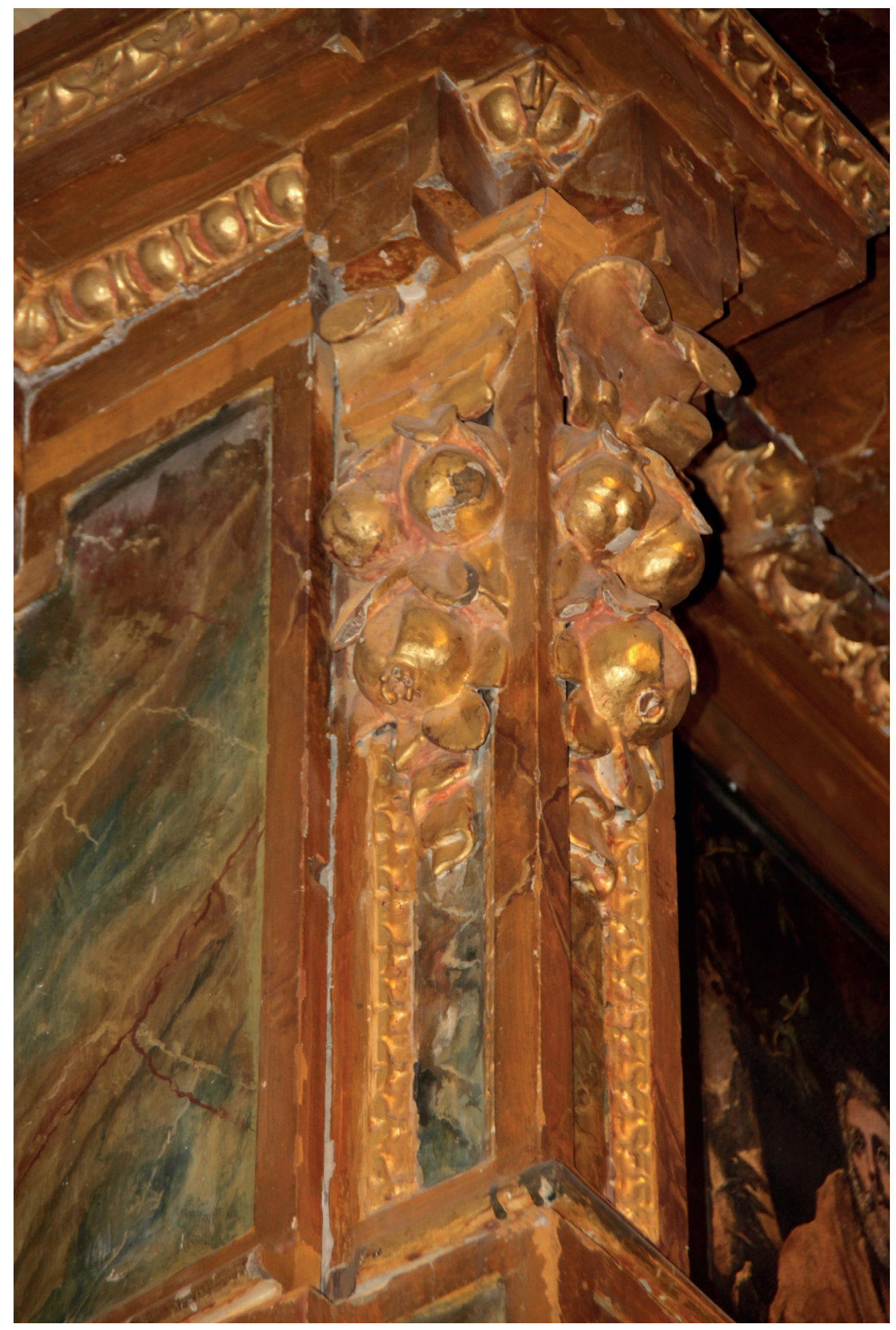

FIGURA 6. DETALLE DEL ÁTICO

Nambroca (Toledo). Iglesia parroquial. Retablo «mayor». 
el siglo xvili. Incluso tras la exclaustración y con el traslado al entonces desocupado templo trinitario de la parroquialidad de San Marcos con algunos de sus enseres desde la iglesia de El Salvador, esta capilla colateral de la cabecera se mantenía aún en I920 sin muchas alteraciones en su mobiliario pues allí se describe este retablo que se califica de corintio y que se advierte ser propio del antiguo convento y no procedente de otra institución o parroquia, y con el Cristo de la Buena Muerte por titular, al que acompañaban otras esculturas traídas, eso sí, de la itinerante parroquia mozárabe ${ }^{50}$.

El retablo tal y como hoy se conserva en su forzada ubicación actual está literalmente encajado en un testero poco adecuado de la iglesia parroquial de Nambroca (Toledo), instalado directamente sobre el suelo y rozando con el frontis superior en el cielo raso del presbiterio por lo que su entera visión sólo se abarca desde una posición lateral (FIGURA I). Todo él está policromado al estilo neoclásico con jaspeados y cajeados marmóreos de tonalidad verde que ponen fondo a los elementos dorados de talla, fruto del revestimiento realizado en $179 \mathrm{O}^{5 \mathrm{I}}$.

Se mantiene aparentemente completo, salvo pérdida de algún aderezo decorativo que formase los remates, y consta básicamente de un pedestal de netos lisos sobre una base de 2,90 m. de anchura, de un cuerpo principal de columnas acanaladas de capitel compuesto con la hornacina central sobreelevada y dentro de la que se acomoda el sagrario original exento (FIGURA 7), aunque renovadas sus columnillas y sin adosar al pedestal, a los pies de una imagen de Cristo crucificado, y terminando en un ático superior apilastrado que contiene una pintura de las Lágrimas de San Pedro, conocida copia de El Greco.

El retablo, para nada plano, sobresale gradualmente con el escalonamiento de las cuatro columnas, por lo que sus laterales añaden cierto movimiento a la unitaria composición frontal. En su alzado, de unos 5,50 m., muestra un pedestal que avanza en tres planos hacia el centro para sustentar el cuerpo principal, centrado

\footnotetext{
otros materiales para la dicha obra, y dado mas de çien sillares, en qu- a sido utiliçado el convt. ${ }^{\circ}$ en gran suma de maravedis» y en agradecimiento se le cede el sitio de la capilla colateral del Evangelio de dicha capilla mayor para que continuase labrándola hasta su conclusión, pero guardando la traza del maestro que trazó toda la capilla mayor para corresponderse con la del otro lado y «a de sacar tribuna desde su casa a la dicha su capilla poniendo balcon y aderezo necessario y quedando mudado a dicha capilla el cumplimiento de sus capellanias y memorias» (exhibiendo licencia del superior dada en Madrid a 31 de julio de 1672). Los lazos de la familia toledana de los Hurtado con la orden trinitaria se afianzan al tener una rama de este apellido su casa solariega medianera con el costado oriental del templo y una capilla funeraria en el lado del evangelio con su reja (AHPT, Pr. 3591, fol. 210, e. Jacinto Sánchez del Prado). En 19 de abril de 1681 otorgaba testamento el regidor de Toledo don Gonzalo Hurtado de Arteaga, caballero de Santiago y Familiar del Santo Oficio, hijo de Jerónimo Hurtado, Familiar y Regidor, y de doña María de Arteaga, y ordena ser sepultado «en la boveda del altar deel Santto Xptto colateral del Ebangelio del convento de la santtisima Trinidad Calzada destta Ciudad de que soy patrono y en que esttan entterrados los dhos mis padres...», vinculando a su mayorazgo, que hereda su hijo Rafael Hurtado de Herrera, sus casas principales «contiguas al conventto de la Santissima Trinidad de esta ciudad» (AHPT, Pr. 3436, fol. 480, e. Eugenio de Valladolid).

50. Ramírez de Arellano, Rafael: Las Parroquias de..., p. 197. En su descripción se añade que el retablo tenía arriba un escudo de los «Goyena», que pudo ser un añadido. Ciertamente en 1706 los maestros de obras citados eran los encargados de la obra de esta capilla llamada de los Hurtado, y para la capilla se hizo en 1769 una reja con su cartela y escudo por el cerrajero José Antonio Cano poniendo las armas de los Hurtado, vid. RAmírez de ARELLANo, Rafael: Catálogo de artífices que trabajaron en Toledo. Toledo, 2002 (ed. facs. Toledo 1920), p. 12, 73 y 43.

51. En este año el pintor Manuel Pérez Maroto junto al dorador Francisco Pérez Tornilari pintaba y doraba el retablo mayor de la capilla de los Hurtado, en precio de 1.196 reales y 17 maravedíes, vid. RAmíREZ DE ARELLANO, Rafael: Catálogo de artífices..., p. 225 y 226.
} 
por una profunda y alta caja arquitrabada que se realza por gruesa moldura tallada quebrada arriba en orejetas que dibujan los contornos superiores de la cruz (FIGURA 2). Esta calle única se comprende entre dos laterales propiamente arquitectónicos, cada uno de ellos compuesto en primer plano de una columna exenta, antepuesta a un ángulo de traspilastras cajeadas, y una media columna retraída en el extremo que crea un flanco escalonado. Sendos trozos de entablamento muestran en su friso cartelas prominentes de talla naturalista (hojas y fruto) contra una moldura de ovas con que se adorna la sencilla cornisa, cuyo tablero sirve de apoyo a un cuerpo intermedio articulado por dos machones a plomo que acompañan la sobre elevación de la hornacina central, y rematados por la complicada cornisa principal que marca la línea completa de separación con el ático. En esta cornisa se disponen modillones al modo vignolesco y queda ocupada en su centro sobresaliente por una característica tarjeta dorada de hojas duras cactáceas, muy extendida y flanqueada por dos cabezas de querubes, que por contraste se hallan blanqueadas (FIGURAs 3, 4 y 5).

Como decimos, sobre esta base se alza un ático más reducido pero bien proyectado hacia adelante, dotado de pedestalillo liso, dos machones labrados a tres caras (FIGURA 6) y sendos contrafuertes retranqueados con festón de frutas y avolutados; quedando en el centro un marco cuadrangular donde tiene cabida la pintura y perfilado por moldura en orejetas que abre sitio a la tarjeta que corona el frontoncillo de cierre curvilíneo.

La tipología de este retablo de altar o capilla habría que relacionarla de inmediato con el retablo de la capilla de San Marcos de la iglesia parroquial de Martín Muñoz de las Posadas (Segovia), de I643, o con los colaterales del santuario segoviano de la Fuencisla, de I645, que se conciben en lo fundamental bajo la misma idea unitaria y compositiva de potenciación de un cuerpo único. Aunque en estos casos la hornacina de medio punto sólo asciende hasta la cornisa principal, en el retablo toledano encontramos como singularidad la hipertrofia de la hornacina que obliga al primer cuerpo a cargar con un montante suplementario y a la reducción en mayor medida del segundo cuerpo. En lo decorativo el uso de tarjetas es más limitado en los mencionados retablos segovianos, incluso con carencia de modillones barrocos en el friso del primero de ellos, los que sin embargo incorpora el retablo toledano, aunque sin ser pareados como en el caso del retablo mayor de Pinto. El retablo toledano no ofrece el tipo habitual de festón bajo cabeza de querubín y sí unas placas recortadas a modo de taco prismático encapitelando machones o pilastras cajeadas, que se atisban en dibujos decorativos de Alonso Cano o de Herrera Barnuevo ${ }^{52}$.

El retablo toledano aquí descrito añade los buscados efectos del claroscuro en el juego de planos y colocación opuesta de elementos y asimila en lo decorativo el lenguaje desarrollado por Pedro de la Torre en su obra coetánea como es el trono de la Virgen del Sagrario, planteado en I647, y cuya maqueta ofrece en ambos entablamentos modillones de hojas. Por tanto, el retablo incorpora los elementos

52. Vv.AA.: Alonso Cano. Dibujos. Catálogo de la exposición, Museo Nacional del Prado (2 de abril/24 de junio del 2001), Madrid, 2001. Díaz García, Abraham: «Sebastián de Herrera Barnuevo (1619-1671). Obra pictórica», en Cuadernos de Arte e Iconografía, Madrid, 37 (2010) pp. 8-251. 


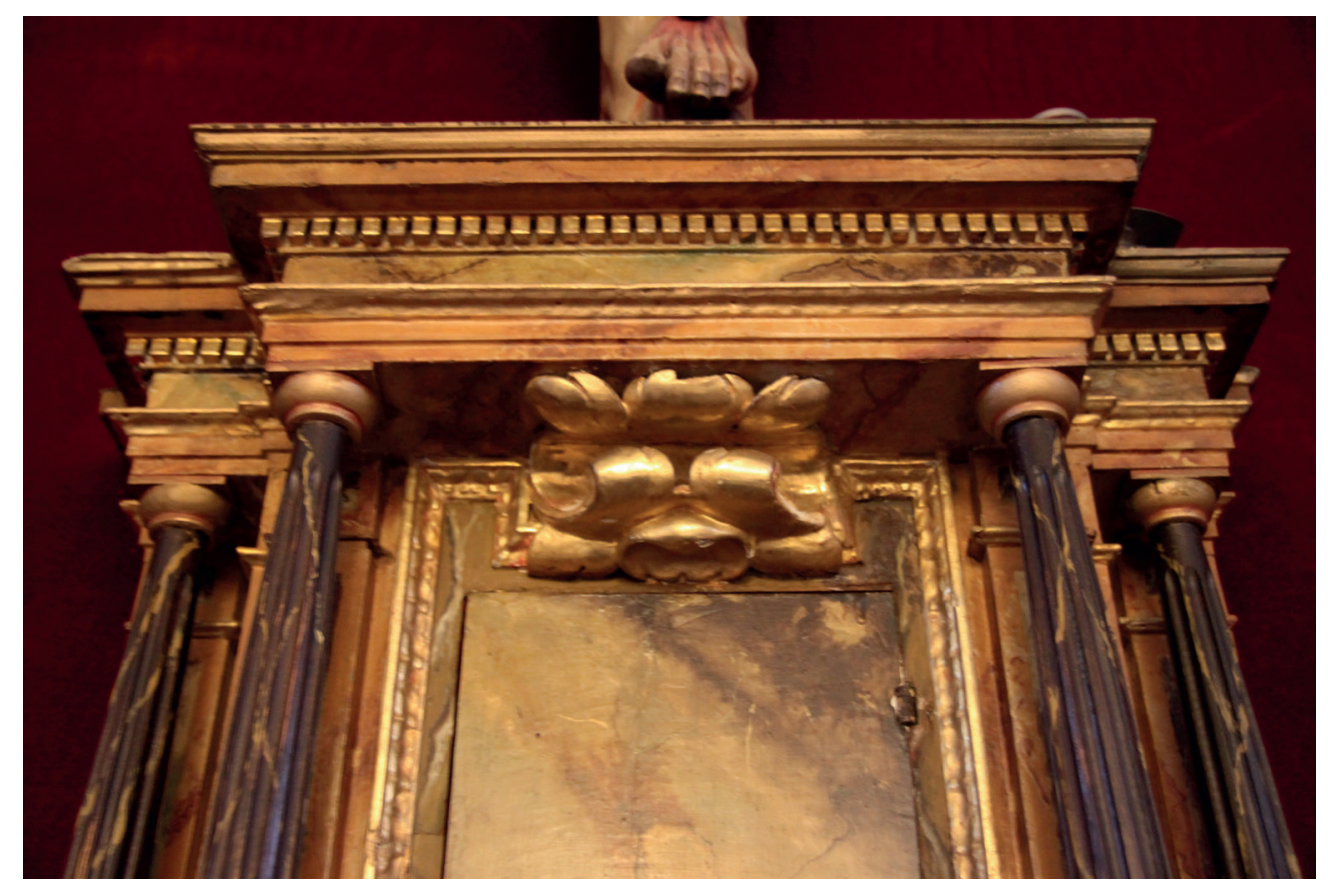

FIGURA 7. DETALLE DE LA CUSTODIA DEL RETABLO «MAYOR» Nambroca (Toledo). Iglesia parroquial.

característicos como son modillones en el friso, tarjetas de hoja canesca en el remate de los cuerpos, festones de frutas, cabezas de querubes y molduras de rica talla ${ }^{53}$. Así mismo, la llamativa tarjeta explayada sobre la cornisa es muy coincidente con la que se ve en las fotografías del desaparecido retablo mayor de Orgaz o bien en el retablo mayor de la iglesia parroquial de San Pedro de Fuente el Saz (Madrid), obra ésta de su hermano José de Torre y de $1655^{54}$. Además, el mencionado retablo orgaceño presentaba no sólo los modillones del friso sino también un marco arquitrabado y de orejetas para la pintura de Rizi que nos recuerda el perfilado de la caja de este retablo de Nambroca.

En definitiva, es este retablo de procedencia toledana una nueva obra a incluir en el catálogo de las trazadas por Pedro de la Torre a partir de i650 y que fue realizada por un necesario colaborador toledano, el ensamblador Juan García de San Pedro, entre I652 y i653. Por otra parte, con esta obra propiamente retablística, la

53. En este sentido, la conformación de algunos de estos elementos de talla adheridos a la estructura del retablo se prefigura en Madrid con la llegada del italiano Juan Bautista Crescenzi para dirigir la decoración del Panteón Real de El Escorial, y se asume y difunde plenamente en el medio madrileño tanto por Alonso Cano como por Pedro de la Torre y otros artistas que la hacen peculiar e inherente al carácter del retablo barroco, vid. PÉREZ SÁNCHEZ, AIfonso E.: «Retablos madrileños del siglo xvıı», en Retablos de la Comunidad de Madrid, Guías del Patrimonio Histórico, Comunidad de Madrid, 2002, pp.63-68.

54. Barrio Moya, José L.: "José de la Torre y Francisco de Ricci, autores del retablo mayor de la iglesia de Fuente el Saz del Jarama», Anales Complutenses, 12 (2000), pp. 43-54. Incluso la estructura del altillo es la solución aportada por el retablo toledano y que permite la sobre elevación del medio punto principal. Un paso estructural hacia la transformación del ático que se da ya en el retablo mayor del monasterio de San Plácido de Madrid, obra conjunta de Pedro y de José de la Torre a partir de 1658. 
especialidad que acredita la supremacía artística de Pedro de la Torre en su época, se introducía en la ciudad de Toledo a modo de primicia un retablo de caracterización barroca y de presumible impacto en los artistas locales del tercer cuarto del siglo xvı en Toledo, muy proclives al cambio de tendencia estilística. 


\section{APÉNDICE DOCUMENTAL}

Contrato de retablo. Toledo, i6 de agosto de I652 (AHPt, Pr. 3404, fol. 459, e. Alonso de Galdo).

Obligacion de retablo. En la ciudad de Toledo diez y seis de agosto de mill seiszientos y cinquenta y dos años ante mi el scr. ${ }^{\circ}$ publico $y$ testigos parezieron el jurado don gonzalo hurtado vezino deesta ciudad de la una parte y de la otra Pedro de la torre vezino de la billa de madrid y Juan garzia de san Pedro vezino deesta ciudad maestros en arquitectura ambos a dos juntos y de mancomun y a boz de uno y cada uno de ellos y de sus bienes por sí e por el todo ynsolidum renunziando como renunziaron las leyes de la mancomunidad escesion y dibision de bienes y de todas las demas que son en fabor de los que se obligan de mancomun en todo y por todo como en ellas se contiene y otorgaron que se obligan dichos Pedro de la torre y Juan garzia de san Pedro en fabor de el dicho Jurado don gonzalo hurtado de hazer un Retablo para el sitio y pilar toral lado del ebanjelio del altar mayor de la yglesia del monasterio de la santisima trenidad de calzados deesta ciudad por el prezio en la forma y con las condiziones siguientes:

-Primeramente que dicho Retablo a de ser de buena madera de Cuenca seca y de buena calidad de manera que no tenga cossa que le perjudique para su adorno durazion y perpetuidad.

-Es condizion que se a de hazer de mui buen ensamblaje y talla de lo mejor que se labra en la billa de madrid corte de su majestad sin escusar ningun jenero de trabajo para la perfeczion de dicha obra.

-Es condizion que se a de ajustar y asentar a vista de dichos maestros en conformidad de la planta y alzado la qual queda firmada de dichos dos otorgantes y el presente $s c r{ }^{\circ}$ y empoder de dichos maestros para obserbarla en las partes y en el todo conforme a mui buena arquitectura la qual a de tener al fin la obra labrada en blanco para que juzguen y bean el maestro o maestros que se nombraren por ambas partes se a cumplido con ella y sus condiziones y no abiendose cumplido se pueda buscar persona o personas que le acaben en toda perfeczion segun la dicha planta y condiziones a costa de dichos maestros.

- Es condizion que la custodia que por la planta demuestra tener seis colunas a de tener tan solamente quatro colunas aRimandola a el pedrestal por el yncombeniente que tendra su mucho reliebo y en lugar de las dos colunas que se le quitan se le añidira algunos adornos y dentellones en el frontis pizio y cornisa dejandolo todo a satisfazion como dicho es de dos maestros que se an de nombrar por ambas partes.

- Toda la qual dicha obra acabada en blanco segun ba rreferido por prezio de ocho mill y quinientos Reales de bellon quel dicho don Gonzalo hurtado se obliga de pagar a dichos maestros a cuya quenta reziben de presente mill Reales de contado de que dichos maestros se dan por contentos pagados y entregados a su boluntad que renunzian las leyes de la entrega y de la paga y demas del casso y de dichos mill Reales dicho Juan garzia de san pedro tiene dado Rezibo y se entienda este y el ser una misma cossa. 
- Y quatro mill y setezientos Reales dicho don gonzalo hurtado le a de pagar dentro de tres meses de oy dia de la fecha y mill Reales como se fuere haziendo dicha obra=y lo restante cumplimento a los dichos ocho mill y quinientos Reales en estando acabada y sentada dicha obra $=y$ qualquier cantidad de todo ello que se diere y pagare el dicho Juan garzia de san pedro la den por bien echa y pagada como si ambos a dos maestros se diera y entregara= los quales se obligan de dar dicha obra acabada y sentada en toda perfezcion dentro de un año desde oy dia de la fecha y so la pena referida de que dicho don gonzalo hurtado pueda buscar quien la hacabe a costa de dichos maestros a cuyo cumplimiento y paga de todo lo que dicho es ambas partes cada una por lo que le toca y ba referido obligaron sus personas y bienes abidos y por aber dieron poder a las Justizias de su majestad de qualesquier partes a cuya jurisdizion se sometieron espezialmente a la de esta Ciudad de Toledo renunziaron su propio fuero jurisdizion y domizilio y la ley si combenerit de juridiczione omnium judicum para que por todo rigor de derechos les apremien a lo cumplir y pagar por bia ejecutiba con costas como por sentenzia pasada en cossa juzgada renunziaron las leyes de su fabor la jeneral y sus derechos y lo otorgaron y firmaron a quienes yo el scr. ${ }^{\circ}$ doi fee conozco siendo testigos don melchor de abila y obiedo christobal perez y diego fernandez hurtado vezinos de Toledo $=$ tachado $=\mathrm{y}$ ochozientos $=$ entre renglones $=\mathrm{y}$ quinientos $=$ balga $=$

D.Gonzalo Hurtado. P. ${ }^{\circ}$ de la torre. Ju. ${ }^{\circ}$ garzia de S.P. ${ }^{\circ}$ Paso ante mi Alonso de Galdo Scr. ${ }^{\circ}$ ppb. ${ }^{\circ}$ Derechos dos rreales dff. ${ }^{{ }{ }{ }}$ 


\section{Dossier Cómplices Necesarios por Carlos Reyero Hermosilla - Dossier Necessary Accomplices by Carlos Reyero}

2) CARLOS REYERO

Introduction: Necessary Accomplices / Presentación: Cómplices necesarios

25 Encarna Montero Tortajada

The Oligarch and the Brushes: a Biographical Sketch of Andreu Garcia, priest / El oligarca y los pinceles: breve semblanza del presbítero Andreu Garcia

María Alegra García García

Some aspects about archbishop of Toledo don Juan Martínez Silíceo's iconography (c.1477-1557) / Algunos aspectos en torno a la iconografía del arzobispo de Toledo don Juan Martínez Silíceo (c.1477-1557)

\section{FELIPE PEREDA}

Performing Doubt: the Art of Believing in Early Modern Spain / El ejercicio de la duda: el arte de creer en la España alto Moderna

\section{Jesús-PEdRo LoREnTE LORENTE}

The mouseion ideal reinterpreted as art colony on the outskirts of Darmstadt and Hagen / El ideal del mouseion reinterpretado como colonia artística en las afueras de Darmstadt y Hagen

\section{9}

NÚRIA FERNÁNDEZ RIUS \& NURIA PEIST

The photographic and the mediation system. Artistic, technical and commercial values in the beginning of photography / Lo fotográfico y el sistema mediador. Valores artísticos, técnicos y comerciales en los inicios de la fotografía

\section{Elena Marcén Guillén}

Real museum, imaginary museum. Considerations around the concept of museum as metamorphosis scenery / Museo real, museo imaginario. Reflexiones en torno al concepto de museo como escenario de metamorfosis

147 VICENÇ FURIÓ

Fame and prestige: necessary and decisive accomplices in the case of Hilma af Klint / Fama y prestigio: cómplices necesarios y decisivos en el caso de Hilma af Klint

\section{Miscelánea $\cdot$ Miscellany}

De la aljama a la primitiva construcción gótica. Reflexiones a propósito de la Catedral de Jaén en época bajomedieval / From the Great Mosque to the former Gothic construction. Some observations on Jaén's Cathedral during the late middle ages
199

TERESA IZQUIERDO ARANDA

Carpintero y maestro constructor en la arquitectura gótica valenciana / Carpenters and building mason in the Gothic architecture in Valencia $\left(14^{\text {th }}-15^{\text {th }}\right.$ centuries)

223

ANTONIO JosÉ DíAZ FERNÁNDEZ

El arquitecto madrileño Pedro de la Torre en Toledo y un retablo inédito localizado / The Architect of Madrid Pedro de la Torre in Toledo and a located unpublished altarpiece

24.7 Fernando R. Bartolomé García \& Laura Calvo García

Transformaciones en el retablo mayor de San Miguel Arcángel de Lazkao (Gipuzkoa). Del Barroco al Neoclasicismo / Changes in the main altarpiece of Saint Michael the Archangel in Lazkao (Gipuzkoa). From Baroque to Neoclassicism

\section{Francisco JaVIER LÁZARO SEBAStiÁN}

La renovación de la fotografía española a partir de la pauta estética del realismo. Un precedente formal y significativo en el reportaje de Eugene Smith sobre Deleitosa (Cáceres) / The renovation of the Spanish photography from the aesthetic guideline of the realism. A formal and significant precedent in Eugene's Smith photographic article on Deleitosa (Cáceres)

277 Javier Cuevas del Barrio

El posicionamiento de Sigmund Freud ante el Surrealismo a través de la correspondencia con André Breton / The position of Sigmund Freud regarding Surrealism through correspondence with André Breton

295 Alicia SÁnCHEZ ORTIZ

El vacío iluminado del negro / The illuminated void of black

317 Óscar MuÑoz Sánchez

Santiago Serrano (1970-1980): Hacia una pintura no aprehensible / Santiago Serrano (1970-1980). Towards a non-apprehensible painting

347 Antonio Jesús Sánchez FERnÁndeZ

Restauración y metamorfosis de los valores del patrimonio cultural / Restoration and Metamorphosis of the Values of Cultural Heritage

\section{Reseñas · Book Review}

375

Aricò, Nicola. Architettura del Tardo Rinascimento in Sicilia. Giovannangelo Montorsoli a Messina (1547-57). Firenze, Leo S. Olschi Editore, 2013. (AlICIA CÁmARA MuÑoz)

Combalía, Victoria. Dora Maar. Barcelona, Circe, 2013. (AMPARO SERRANO DE HARO)

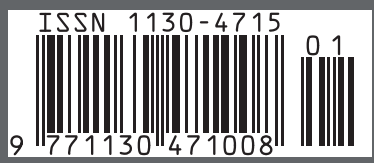

